\title{
TEN ADVERSE OUTCOMES WHEN MANAGERS FOCUS ON CREATING SHAREHOLDER VALUE: A REVIEW
}

\section{DIEZ RESULTADOS ADVERSOS CUANDO EL GERENTE SE ENFOCA EN CREAR VALOR PARA EL ACCIONISTA: UNA REVISIÓN BIBLIOGRÁFICA}

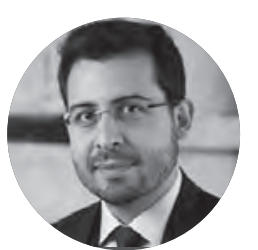

\author{
Alexandre Di Miceli \\ ORCID: 0000-0002-4864-9429 \\ Escola de Negócios \\ Fundaçao Armando Alvares \\ Penteado \\ Saö Paulo - Brazil \\ alexandre@direzione.com.br
}

Recibido: 31 de agosto de 2018

Aprobado: 09 de noviembre de 2018

Cómo citar este artículo:

Di Miceli, A. (2018). Ten adverse outcomes when managers focus on creating

shareholder value: A review. Review of Global Management, 4(2), 79-107.

\section{RESUMEN}

Esta monografía examina la literatura que critica la gestión de negocios orientada a crear valor para los accionistas exclusivamente, por la vía de la maximización de los precios de sus acciones. Con base en un enfoque multidisciplinario, se revisan investigaciones empíricas y teóricas de campos como el derecho corporativo, la administración, las finanzas, economía, la ética empresarial, psicología social y la sociología de las organizaciones. Se destacan diez principales efectos perjudiciales de la adopción del paradigma del valor para el accionista en la administración de empresas. Se contribuye con la literatura,adicionalmente, presentando evidencia anecdótica a través de casos breves de negocios que ilustran estos resultados adversos. En conjunto, esta creciente literatura proporciona evidencia convincente de que gobernar las compañías para maximizar los precios actuales de sus acciones podría tener severas consecuencias negativas para todos los constituyentes corporativos, incluida la sociedad civil y los propios accionistas.
Palabras clave: Maximización del valor del accionista, gobierno corporativo, cortoplacismo, propósito empresarial.

\section{ABSTRACT}

This paper surveys the literature criticizing the view that managers should run companies aiming to create shareholder value by maximizing stock prices. Based on a multidisciplinary approach, I include empirical and theoretical papers from fields such as corporate law, management, finance, economics, business ethics, social psychology, and sociology of organizations. Ten main harmful effects from the adoption of the shareholder value paradigm stand out. I also add to the literature by presenting anecdotal evidence through short business cases illustrating these adverse outcomes. Together, this growing literature provides compelling evidence that governing companies in order to maximize current stock prices might lead to severe negative 


\section{REVIEW}

OF GLOBAL

MANAGEMENT

FACULTAD DE

NEGOCIOS

UPC

consequences for all corporate constituencies, including society and shareholders themselves.

Key-Words: shareholder value maximization, corporate governance, "short-termism", company purpose, survey.

JEL Classification Codes: G30, G32, G34, K22, L21, M14, M19, M20.

\section{INTRODUCTION}

"The social universe has no "natural laws"... This means that assumptions that were valid yesterday can become invalid and, indeed, totally misleading in no time at all".

Peter Drucker (1909-2005) ${ }^{1}$

${ }^{1}$ Source: Drucker. P. 2008. The Essential Drucker: The Best of Sixty Years of Peter Drucker's Essential Writings on Management. HarperBusiness. Chapter 6.

${ }^{2}$ The term "managers" in this paper encompasses both c-level officers as well as board members.

${ }^{3}$ The corporate governance movement and the shareholder value approach to business, in turn, were strongly grounded on agency theory formulated by Jensen and Meckling (1976). The adoption of agency theory as the basis for management education on corporate governance contributed to the creation of the shareholder value paradigm and to its diffusion among market practitioners. ${ }^{4}$ The term "shareholder value" has been used to refer to concepts such as that:1) managers should make decisions aiming to maximize shareholders' claims through increases in stock prices and cash distributions; 2 ) the best measure of the firm's value to stockholders is given by its market capitalization on stock markets; or, 3) managers should only approve investments if their expected return outperforms the cost of capital of the firm. Rappaport (1986) has introduced the use of "shareholder value" as a managerial tool in the 1980s ("The ultimate test of corporate strategy, the only reliable measure, is whether it creates economic value for shareholders"). In this paper, I refer to shareholder value maximization as the managerial practices and strategies intended to maximize stock prices.

${ }^{5}$ Since the economic concept of "value" depends on the net present value of future cash flows available for financial claimants in an undefined period of time, the paradigm of maximizing shareholder value could be understood, in theory, from the perspective of making stockholders as rich as possible in the long run. In practice, though, the doctrine has been translated into the frantic search
The corporate governance movement has been strongly grounded on the view that managers ${ }^{2}$ primarily role is to create shareholder value, since its inception in the $1980 \mathrm{~s}^{3}$. Although the term "shareholder value" is interpreted in different ways ${ }^{4}$, this paradigm asserts that a well-governed company is one in which managers seek to maximize stockholders' wealth, as measured by its stock price ${ }^{5}$. The orientation to maximize shareholder value has become the (explicit or implicit) basis for several codes of best practices, as well as for the approval of regulations aiming at strengthening shareholder rights and investors' activism ${ }^{6}$. As a result, listed companies worldwide during the past three decades have been urged to change their governance structures in order to "unleash" higher shareholder value by:

- Increasing the number of independent directors in order to enhance board independence;

- Implementing equity-based compensation; for maximizing current stock prices. To illustrate this point, the average holding period of stocks from companies belonging to the S\&P 500 index fell from eight years in 1960 to around four months in 2013. In addition, the average tenure of CEOs from listed companies has also been halved in the U.S. since the 1970s (details ahead in the paper). Both investors and executives, therefore, are more and more oriented towards short-term results. It is also important to note that the idea that managers should create shareholder value through the maximization of stock prices is fully dependent on the informational efficiency of stock markets. Source of data: The Purpose of the Corporation Project (http://www.purposeof corporation.org/cs).

${ }^{6}$ The view that shareholder wealth maximization was the only proper goal of corporate governance was considered a settled issue in the late 1990s. Hansmann and Kraakman (2001) statement illustrate this in their widely-cited article: "there is no longer any serious competitor to the view that corporate law should principally strive to increase long-term shareholder value. The principal elements of this emerging consensus are that ultimate control over the corporation should rest with the shareholder class; the managers of the corporation should be charged with the obligation to manage the corporation in the interests of its shareholders... and the market value of the publicly traded corporation's shares is the principal measure of its shareholders' interests". Stout (2012) summarizes the prevalence of this view: "Most scholars, regulators and business leaders accepted without question. Shareholder primacy had become dogma, a belief system that was rarely questioned, seldom explicitly justified, and had become so pervasive that many of its followers could not even recall where or how they had first learned of it" (p. 21). 
- Dismantling most anti-takeover devices to facilitate the market for corporate control 7 ;

- Promoting greater convergence of control rights and cash flow rights through the increased adoption of the one share-one vote rule; and,

- Facilitating shareholder activism through statutory modifications and friendly procedures at shareholder meetings.

In spite of all these relevant changes, though, few would say that the corporate governance movement has managed to turn corporations around the world into more genuinely accountable, responsible, transparent and sustainable organizations in the past decades.

Possibly on the contrary. During this period, successive scandals and crises have characterized the business environment. In the U.S. market, for instance, the 2000 s was marked by the wave of accounting frauds in 2001-2002, the stock option backdating scandal in $2005^{\circ}$, and the collapse of systemically critical financial institutions that caused the 2008 global financial crisis.

In addition, major scandals involving the payment of large -scale bribes (e.g. Siemens in 2006 9 , and Alstom in $2011^{10}$ ); money laundering (e.g. Olympus in 2011 ${ }^{11}$, HSBC in $2012^{12}$, Commerbank in $2015^{13}$ ); siphoning of funds to political parties (e.g. Petrobras in $2014{ }^{14}$ ), and ecological disasters motivated by bad governance practices (e.g. BP in $2010^{15}$ ), have eroded the trust in business worldwide.

In this sense, a survey conducted by the Edelman Institute in 2013, with 30,000 people from around the world, found

\footnotetext{
${ }^{7}$ Given the dismantling of most anti-takeover devices, the boosting of stock prices has been seen by managers as one of the best defense against a hostile takeover.

${ }^{8}$ In 2005, a paper by Lie (2005) showed that around 2,000 U.S. companies have altered the date in which stock option plans were granted to its executives to dates immediately before sharp increases in stock prices. This practice increased substantially managers' compensation, leading to a SEC investigation. More than 130 companies have been identified as practicing improper backdating, resulting in the firing or resignation of more than 50 top managers. ${ }^{9}$ See New York Times. At Siemens, bribery was just a line item. Dec 20th 2008 .

10 See New York Times. Alsom to plead guilty and pay U.S. a US\$772 million fine in a bribery scheme.

${ }^{11}$ See Bloomberg Businessweek. The Story Behind the Olympus Scandal. Feb 16th 2012.

12 See Bloomberg. HSBC Judge Approves \$1.9B Drug-Money Laundering Accord. Jul 3rd 2013.

${ }^{13}$ See Financial Times. Commerzbank makes \$1.45bn settlement with US. Mar 12th 2015.

${ }^{14}$ See Financial Times. Petrobras scandal knocks broader Brazilian
}

that only $18 \%$ believe that business leaders are trustable to tell the truth and reliable to make ethical decisions ${ }^{16}$. Two other polls carried out by the Gallup Institute in the U.S. reinforce this conclusion. The first shows that the public satisfaction with the size and influence of major corporations reached a record low of 30\% in 2012, against 50\% ten years before ${ }^{17}$. The second shows that only $21 \%$ of the population demonstrate a great deal or quite a lot of confidence in big business as an institution in $2014^{18}$.

For a growing number of scholars from different fields, such as corporate law (Stout, 2002, 2010, 2012a, 2012b, 2013, 2014; Masouros, 2012; Armour and Gordon, 2014; Sjåfjell and Mähönen, 2014), management (Martin, 2010, 2011; Mayer, 2013), economics (Lazonick and O'Sullivan, 2000; Lazonick, 2008, 2009a, 2009b, 2010, 2011), political economy (Pearlstein, 2014), finance (Montier, 2014), business ethics (Palazzo et al. 2012; Gonin et al. 2012), and sociology of organizations (Finglestein, 2001; Finglestein and Shin, 2004, 2007; Jung, 2015; TomaskovicDevey et al. 2015), the root of the problem stems from the adoption of shareholder value as the guiding principle for the corporate governance movement ${ }^{19}$. Even conservative and pro-business publications, such as the Financial Times, have started to question the cult to shareholder value. Martin Wolf, its chief economics commentator, stated in 2014 that "almost nothing in economics is more important than thinking through how companies should be managed and for what ends. Unfortunately, we have made a mess of this. That mess has a name: it is shareholder value maximization" 20 . These critics argue that the managerial focus on shareholder

oil industry. Mar 25th 2015.

${ }^{15}$ See Reuters. U.S. judge upholds BP 'gross negligence' Gulf spill ruling. Nov 13th 2014.

${ }^{16}$ Edelman trustbarometer 2013. Annual Global Study. Available at http://www.edelman.com/insights/intellectual-property/ trust-2013/

${ }^{17}$ Americans Anti-Big Business, Big Gov't 2012. Available at http://www. gallup.com/poll/152096/americans-anti-big-business-big-gov.aspx ${ }^{18}$ Available at http://www.gallup.com/poll/1597/confidenceinstitutions.aspx

${ }^{19}$ In the case of Armour and Gordon (2014), they propose relaxing the mechanisms encouraging shareholder value maximization only for companies that might cause systemic harms to society, such as large financial institutions.

${ }^{20}$ Martin Wolf. Financial Times. Opportunist shareholders must embrace commitment. August 26th 2014. Available at http://www. ft.com/cms/s/0/6aa87b9a-2d05-11e4-911b-00144feabdc0.html 


\section{REVIEW}

OF GLOBAL

MANAGEMENT

FACULTAD DE

NEGOCIOS

UPC

value by maximizing stock prices has generated many negative side effects for stakeholders and society in general, including stockholders themselves. Pearlstein (2014), for instance, argue that shareholder value is nothing more than an ideology that has become corrupted over time to favor a small intellectual elite: "[What] began in the 1970s and 1980s as a useful corrective to self-satisfied managerial mediocrity has become a corrupting self-interesting dogma peddled by finance professors, Wall Street money managers and over-compensated corporate executives" (p. 5).

As a result, an increasing theoretical and empirical literature criticizing the view that managers should run companies aiming to maximize stock prices has emerged ${ }^{21}$. Given the current relevance of this debate, this paper aims to synthetize this literature ${ }^{22}$.

I identify ten main negative side effects for stakeholders and society resulting from governing companies based on the shareholder value paradigm ${ }^{23}$ :

1. Generation of long-term liabilities to be borne by society; 2. Managerial myopia resulting from the focus on meeting analysts' earnings expectations;

3. Underinvestment as a consequence of the increased "financialization"24 of companies;

4. Managerial focus on managing expectations in order to maximize equity-based pay;

5. Increased income inequality within firms and at the society level;

6. Opportunistic behavior of shareholders seeking short-term gains in mergers \& acquisitions;

7. Increased job insecurity, stress and lack of purpose in the organizational environment;

8. Promotion of amoral behavior and ethical blindness;

${ }^{21}$ Early literature criticizing shareholder value as a managerial paradigm is provided by Aglietta (2000), Lazonick and O'Sullivan, (2000), Finglestein (2001), and Stout (2002). For Lazonick and O'Sullivan (2000), for instance, shareholder value is a term emerged under neoliberalism that changed managers' strategic orientation from a philosophy of "retain and reinvest" towards a philosophy of "downsize and distribute".

${ }^{22}$ Although the critics in the literature are more closely related to large listed companies with dispersed ownership structure typically observed in Anglo-Saxon countries, the negative-side effects presented may also be present in companies with controlling shareholders that are the norm around the world. As a result, I provide anecdotal evidence on the pervasiveness of such adverse outcomes through short business cases involving Brazilian companies.

${ }^{23}$ Stout (2013) details another "toxic side effect" (in her words) of
9. Deterioration of long-term firm performance; and,

10. Worst long-term outcomes for the capital markets, the environment and universal investors.

In the following sections, I detail each one of these negative implications, including their rationale and empirical evidence. The last section concludes this research by integrating all adverse consequences into a single framework.

\section{GENERATION OF LONG-TERM LIABILITIES TO BE BORNE BY SOCIETY}

Society grants stockholders of publicly-held companies the privilege of limited liability, a form of subsidy that avoids shareholders to bear the full cost of its company's actions. But limited liability can generate a perverse incentive. If legal mechanisms, such as regulations, fail to ensure that all the firm's costs are fully internalized by the company, then it will be rational for stockholders (especially in the case of short-term investors) to pocket the firm's earnings as quickly as possible, while leaving long-term liabilities to society.

This is what happened in the 2008 global financial crisis. Executives from financial institutions and many fund managers cashed huge gains in the pre-crisis years. When the collapse occurred, however, stakeholders and society had to bear most of its costs. According to Mayer (2013), since shareholders are subject to limited liability, it was rational for many investors during this period to encourage bank officers to roll the dice in a game of "heads I win, tails you lose" 25 .

shareholder primacy: the extraction of shareholder value at the expense of creditor's welfare. This issue is not discussed in this paper.

${ }^{24}$ According to Van der Zwan (2014), financialization refers to the web of interrelated process - economic, political, social, technological, cultural, etc. - through which finance has extended its influence beyond its traditional role as provider of capital for the productive economy into realms of social life. One of the branches in this literature deals with the financialization of the modern corporation. In this case, it analyzes the increasing financial orientation of non-financial corporations. ${ }^{25}$ According to Mayer (2013, p. 62), highly levered financial institutions had a good chance of getting abnormal gains at the cost of a very small risk of catastrophic losses. If abnormal gains held for a sufficiently long period before the occurrence of large losses, then it would be worth for participants with a short-term time horizon to 
Armour and Gordon (2014) detail the problems of the doctrine of shareholder value maximization in relation to systemic harms. For them: [The] financial crisis has demonstrated serious flaws in the corporate governance of systemically important financial firms. In particular, the norm that managers should seek to maximize shareholder value, as measured by the stock price, proves to be a faulty guide for managerial action in systemically important firms. (p. 35). In particular, the norm that managers should seek to maximize shareholder value, as measured by the stock price, proves to be a faulty guide for managerial action in systemically important firms". Roe (2014) makes a similar argument by pointing out that: [The] basis for questioning the value of shareholder-oriented financial firm governance is straightforward: as long as there is a strong too-big-to-fail subsidy, shareholder interests will find it profitable to take heavy risk, because a significant fraction of the downside is borne by the government or by the overall economy, not by the firm and its shareholders. (p. 1454)

Several empirical papers examining the corporate governance determinants of financial firms' performance during the crisis corroborate the argument that institutions focused on maximizing stock prices imposed higher economic externalities on society. Erkens et al. (2012), for instance, analyze 296 financial institutions from 30 countries at the epicenter of the crisis. They conclude that firms with more independent boards and higher institutional ownership experienced worse stock returns during the 2007-2008 financial crisis. Interestingly, they also note that banks with higher institutional ownership took more risk prior to the crisis, suffering larger losses. According to the authors: A potential explanation for this finding is that independent directors and institutional shareholders encouraged managers to increase shareholder returns through greater risk-taking prior to the crisis. Shareholders may find it optimal to increase risk because they do not internalize the social costs of financial institution failures. (p. 390)

"play the game". Bratton and Whatcher (2010) reach the same conclusion by arguing that: "For a management dedicated to maximizing shareholder value, the instruction manual was clear: get with the program by generating more risky loans and doing so with more leverage. Any bank whose managers failed to implement the new math of high returns with low beta got stuck with a low price... would increased shareholder power have moderated the bank's risky business practices? We think the answer is no" (p. 720). ${ }^{26}$ Beltratti and Stulz (2012) used a RiskMetrics governance index composed by 25 board attributes to measure the alignment of interests between boards and shareholders.

${ }^{27}$ Specifically, they find that banks in which the CRO reports directly to the board of directors perform significantly better in the credit crisis than those in which the she reports to the CEO.
In line with this conclusion, Beltratti and Stulz (2012) analyze 164 large banks from 32 countries and find that those with more shareholder-friendly boards ${ }^{26}$ performed significantly worse during the crisis than other financial institutions. According to the authors: [...] our evidence poses a substantial challenge to those who argue that poor bank governance was a major cause of the crisis [...] The most likely explanation is that shareholder-friendly boards positioned banks in ways that they believed maximized shareholder wealth, perhaps by taking advantage of implicit or explicit governmental guarantees, but left them more exposed to risks that manifested themselves during the crisis and had an adverse impact on banks. In other words, shareholder-friendly boards created more value for shareholders through their decisions before the crisis, but during the crisis these decisions were associated with poor outcomes. (pp. 1-2)

Aebi et al. (2012) find similar results after analyzing 573 U.S. financial institutions. Although their focus is to demonstrate that banks with more independent risk-management departments performed better during the crisis ${ }^{27}$, they also observe that banks' performance is negatively related to governance mechanisms such as board independence. They also highlight that results suggest that "Banks were pushed by their boards to maximize shareholder wealth before the crisis and thereby took risks that were understood to create wealth but later turned out poorly in the credit crisis" (p. 3215). ${ }^{28}$

For Mayer (2013), a similar problem is likely to occur with companies from other strategically important industries that are currently generating potentially explosive future liabilities of all sorts (such as those in the environmental, labor and social areas). The liabilities of these "too-important-tofail" companies ${ }^{29}$ will be largely borne by society--not by its shareholders--since many of them will no longer be active when the problems materialize, while others will simply be

\footnotetext{
28 The lack of an expected positive relation between recommended corporate governance practices and firm performance during the crisis has also been observed for non-financial companies by Gupta et al. (2013). After analyzing 4,406 public companies belonging to a wide range of industries from 22 countries, they find that companies with higher governance quality (measured by a broad-based index), did not out perform those with lower scores.

29 This term was created by Mayer (2013).
} 
not financially capable to cover its costs ${ }^{30}$. He concludes that: It is perfectly rational for companies anticipating potential problems in the future to distribute as much as they can to their current shareholders so that there is as little as possible in the business to pay out in compensation to the victims of the devastation they have caused (p. 66).

\section{MANAGERIAL MYOPIA RESULTING FROM THE FOCUS ON MEETING ANALYSTS' EARNINGS EXPECTATIONS}

The focus on maximizing stock prices usually involves devoting much relevance to meet or beat market's quarterly earnings expectations. The managerial effort to play the "earnings game", in turn, may affect the behavior of company, leading to reduced investments as well as to long-term value destruction.

Graham et al. (2006) provide startling evidence on how managers are willing to alter investment decisions in order to meet expected earnings, even if these decisions sacrifice long-run economic value and hurt stockholders in the long term. After surveying $401 \mathrm{CFOs}^{31}$, they observe that around $80 \%$ would be willing to sacrifice economic value in order to smooth earnings ${ }^{32}$, while $56 \%$ would defer valuable long-term projects in order to meet earnings benchmarks ${ }^{33}$. Around $80 \%$ of CFOs also admit they would decrease R\&D and maintenance expenditures to meet earnings targets, even though many acknowledge that these decisions can be value destroying.

\footnotetext{
30 This problem evidences how shareholders are not the only stakeholders to bear residual risks in the companies. Other stakeholders are also exposed to risks that they cannot be fully protected by contracts or regulations.

${ }^{31}$ Graham et al. (2006) also conducted in-depth interviews with an additional 22 executives.

32 In the authors' words: "We directly asked executives how much they would sacrifice to avoid volatile earnings. An astonishing 78 percent admitted that they would sacrifice a small, moderate, or large amount of value to achieve a smooth earnings path" (p. 33). ${ }^{33}$ In addition, 15 of 20 executive interviewed in person agreed that every company would/should take actions such as the deferral of valuable long-term projects in order to deliver earnings even when there is not a capital constraint, as long as the actions are within GAAP and the real economic sacrifices are not "too large".

${ }^{34}$ Graham et al. (2006, p.38) conclude their paper by saying that "our results suggest that capital investment may not be at its optimal level because of pressures to play the earnings game.
}

The fact that a relevant fraction of around $40 \%$ of managers would clearly reject a positive-NPV project to meet an analyst consensus estimate allows for an estimation of the magnitude of the problem of having current stock prices guide managerial actions. Graham et al. (2006) calculate that a "small sacrifice" of $1 \%$ of economic value by managers to reach market expectations would cost around US\$150 billion per year for the U.S. economy; this is equivalent of "two Enron scandals".

The authors also ask CFOs whom they perceive as the most important person or group when the company establishes its policies on disclosure and earnings recognition. By far, CFOs see stock analysts and institutional investors as their most important audiences. CFOs, therefore, largely see themselves as working for short-term money managers and stock analysts whom they should please in order to maximize stock prices ${ }^{34}$.

Jie and Xuan (2013) also find evidence of negative impacts on the real economy arising from managers' focus on pleasing stock markets. After analyzing 25,860 firm-year observations from 1993 to 2006 in the U.S., they conclude that firms covered by a larger number of analysts generate fewer patents as well as patents with lower impact.

The negative impact of analyst coverage on firm innovation ${ }^{35}$ is consistent with the hypothesis that analysts' pressure on managers to meet short-term earnings goals lead them to try to boost earnings per share by sacrificing investments in long-term innovative projects (especially projects that are highly risky and slow in generating revenues) ${ }^{36}$.

Asker et al. (2015) provide further evidence of the deleterious consequence of trying to maximize current stock prices.

Less investment means less employment. Less investment also negatively affects the ability of companies to compete in the global economic arena".

35 Jie and Xuan (2013) use different variables associated with innovation (such as the number of patents granted and the number of future citations received by each patent) to assess the success of long-term investment in innovation.

${ }^{36}$ The "pressure hypothesis" theorizes the relationship between analyst coverage and innovation. According to Jie and Xuan (2013), "tolerance for failure is necessary for effectively motivating and nurturing innovation. However, the least thing financial analysts can offer to innovative firms is to tolerate short-term failures, as their job is to forecast near-term earnings and make corresponding stock recommendations. Whenever they expect the firms to experience a drop in near-term earnings, they would revise their forecasts downward and make unfavorable recommendations, leading to negative market reactions and potential disciplinary actions against the managers" (p. 857). 
They investigate whether public-firm managers behave in a short-termist way by comparing the investment behavior of comparable public and closely-held private firms of a dataset covering more than 400,000 firm-year observations over the period from 2001 to $2011^{37}$. They reach two main conclusions. First, public firms invest substantially less than do private ones ${ }^{38}$. For instance, after matching on size and industry, public firms increase gross fixed assets by $3.7 \%$ of total assets per year, against the almost double of $6.8 \%$ for private firms ${ }^{39}$. This result is even more surprising given that public companies, in theory, have access to cheaper long-term capital for investments through stock markets ${ }^{40}$. Second, public firms are much less responsive to changes in investment opportunities than private ones, especially in industries in which stock prices are more sensitive to earnings news as well as in the case of companies with high levels of short-term focused institutional ownership ${ }^{41}$.

Asker et al. (2015) findings, therefore, are consistent with the argument that short-term oriented pressures distort investment decisions by inducing public firms to invest myopically ${ }^{42}$.

${ }^{37}$ The paper naturally assumes that closely held private firms are subject to fewer pressure for short-term results.

${ }^{38}$ Authors obtain this result after holding firm size, industry, and investment opportunities constant.

${ }^{39}$ Asker et al. (2015) use several alternative measures of corporate investment obtaining the same results. They show, for example, that private firms continue to outinvest public ones when they compute investment in intangibles in addition to investments in fixed assets.

Rows 5 and 6 show similar patterns for net (rather than gross) investment: private firms invest 2.9 percentage points more in net fixed assets and 4.4 percentage points more when we include intangibles

40 This finding is consistent with a model formulated by Ferreira et al. (2012). Their model shows that private ownership creates incentives for innovation, whereas public ownership disincentivizes innovation. As a result, they conclude that the incentives in public firms are biased toward conventional projects, whereas the incentives in private firms are biased toward innovative projects.

${ }^{41}$ Authors show that private firms' investment decisions are around four times more responsive to changes in investment opportunities than public firms, even during the 2008 financial crisis.

42 There are other examples of the negative impacts for companies and society coming from the focus on meeting markets' earnings expectations. In an earlier study, Bushee (1998) finds that a large proportion of ownership by institutional investors that have high portfolio turnover and engage in momentum trading significantly

\section{UNDERINVESTMENT AS A CONSEQUENCE OF THE INCREASING FINANCIALIZATION OF COMPANIES}

For critics, the increased centrality of the financial industry and the growing power of money managers proclaiming the motto of shareholder value have led companies to undergo a process of "financialization" ${ }^{43}$. As a consequence, non-financial companies 1) increased their activities related to financial markets; 2) became more and more focused on returning cash to shareholders; and 3) were converted into a portfolio of financial assets that might be bought, sold or traded in parts through spin-offs at any time ${ }^{44}$

The main alleged negative implication from this process of financialization is that companies increasingly prioritize returning cash to shareholders ${ }^{45}$ and allocating funds into speculative financial assets ${ }^{46}$ instead of investing in long-term activities with productive purposes (Krippner, 2005, 2011; Lazonick, 2008, 2011; Wolfson and Kotz, 2010;

increases the probability that managers reduce $R \& D$ in order to reverse an earnings decline. More recently, Benner and Ranganathan (2012) find that negative analyst recommendations are associated with reductions in firm capital expenditure and R\&D during times of technological change.

43 The "financialization" of non-financial companies can be measured by the ratio of financial payouts relative to profits as well as by the ratio of financial assets as a share of its total assets.

${ }^{44}$ According to Blackburn (2006), the financialized firm may be called "the disposable corporation" (p. 42). Van der Zwan (2014) details the literature investigating the financialization of the companies and society in different fields of social sciences, such as political economy, sociology and economics.

${ }^{45}$ Kliman and Williams (2015) observe that U.S. corporations are paying out larger sums of cash to financial markets since the 1980s. They observe, for instance, that the share of net operating surplus paid out as dividends was relatively stable between 1957 and 1988, but then rose almost continually to a level more than double that of 1988 .

${ }^{46}$ For instance, Kliman and Williams (2015) observe that non financial U.S. corporations increased their financial assets as a share of their total assets from 36\% to 56\% (a rise of more than 50\%) between 1982 and 2007. In this sense, Stockhammer (2004) argues that a fundamental shift in the priorities of corporate management that has taken place in the past decades, in which corporations have become increasingly rentier-like by using heir profits to acquire financial assets instead of productive ones. 


\section{REVIEW}

OF GLOBAL

MANAGEMENT

FACULTAD DE

NEGOCIOS

UPC

Ott, 2011; Duménil and Lévy, 2011) ${ }^{47}$. The case of share repurchases ${ }^{48}$ in the U.S. market is the clearest example of this criticism. Until the early 1990s, these operations were relatively rare. Pressured by investors to distribute their "surplus" cash in order to keep stock prices at high levels, companies started to buyback their shares in increasing proportions, exceeding the traditional distribution via dividends during the 2000s ${ }^{49}$.

Stocks buybacks reached its apex in 2007, the last year prior to the global financial crisis (when stock prices were at its highest in the decade). That year, S\&P500 companies spent about $\$ 600$ billion to buy back its shares, an incredible $89 \%$ of its aggregate net income. According to Lazonick (2011, p.6), from 2000 to 2009, S\&P500 companies spent $\$ 2.5$ trillion in buybacks (58\% of their net income) and additional $\$ 1.8$ trillion in dividends (41\% of their income) ${ }^{50}$ The result from corporations' increase in payments to financial markets is that, on a macro level, companies have distributed all their earnings as well as shareholders have extracted more money out of public companies in the 2000 decade in the U.S. than they have put in ${ }^{51}$. Even mainstream publications, such as The Economist ${ }^{52}$, recognize that there are reasons to worry with the massive buybacks. It shows that buybacks resumed to the pre-crisis

${ }^{47}$ This third critic, therefore, also relates with the underinvestment resulting from the focus in pleasing market agents. However, in this case the problem deals with the allocation of earned income instead with the management of earnings in order to meet securities' analysts. ${ }^{48}$ Share repurchases (also known as stock buybacks) are the re-acquisition by a company of its own stock. It is another mechanism to return money to shareholders.

${ }^{49}$ Lazonick (2010) details the empirical evidence of the steady increases in dividend and stock buybacks to shareholders in the U.S. market since the 1980s. He also makes an important point about the distinction between share buy-backs and dividends. Whereas share buy-backs involve the sale of stock by investors to the corporation, dividend payouts require a continued ownership of stock by the investors. For this reason, Lazonick (2010, p.696) argues that dividend payouts might actually result in more patient capital than generally assumed.

${ }^{50}$ In addition to repurchases reaching its apex in the year in which stocks peaked in the 2000 s, critics argue that many executives sold shares from their personal accounts while carrying out repurchases on behalf of their companies. Therefore, the argument that stock buybacks add value by signaling to the market that the company's shares are undervalued is severely weakened with this finding. For evidence on this contradictory behavior, see the "Insider Buying Dries Up Defying \$275 Billion of buybacks", Bloomberg, level in the past years, reaching US\$500 billion in 2013. Several companies spent more than $100 \%$ of their cash flows on dividends and buybacks, while many are making use of cheap debt to boost their stock prices. It also highlights that in the 2006-2008 period U.S. financial institutions repurchased around US\$207 billion of their shares, only to receive and injection of around US\$250 billion from taxpayers in 2009 to stay afloat. According to the publication, while everybody is addicted to the temporary pop they give to stock prices, the irrational hunger for cash returns may be contributing to a jobless and "no-investment" recovery.

In sum, the pressure to keep stock prices at the maximum level in order to 1) satisfy investors; 2) defend the company against takeovers; and 3) maximize managers' equitybased compensation, is making companies increasingly repurchasing their shares, which for critics, such as Lazonick (2013), tends to stifle the growth of investment in innovation ${ }^{53}$.
09/22/2014, Available at http://www.bloomberg.com/news/2014-0922/insider-buying-dries-up-defying-275-billion-of-buybacks.html. ${ }^{51}$ As Montier (2014) notes, from the mid-1980s onwards, equity issuance in the U.S. has been net negative as firms have bought back a huge amount of their own equity (often through the issuance of debt. He concludes by saying that "far from providing capital to the corporate sector, shareholders have been extracting it from corporates".

${ }^{52}$ Source: Share buy-backs: the repurchase revolution. Sep 13th 2014. Available at http://www.economist.com/node/21616968 ${ }^{53}$ The view that rising financial payouts have come at the expense of productive investment is not consensual, however. Kliman and Williams (2015), for instance, argue that the relative increase in the financial payments through buybacks and dividends did not lead to a decline in productive investment because they were funded by increases in debt instead of form operational profits. On the other hand, the authors agree with the prior literature on financialization that 1) non-financial corporations have become increasingly financialized; and 2) financial payouts have increased more rapidly than profits since the 1980s. They also observe that the rate of capital accumulation plummeted 67\% from 1979 to the period between 2001 and 2007, while companies substantially increased their acquisition of financial assets in relation to their acquisition of productive fixed assets. 


\section{MANAGERIAL FOCUS ON MANAGING EXPECTATIONS IN ORDER TO MAXIMIZE EQUITY-BASED PAY}

Equity-based pay is a key recommendation arising from shareholder value ideology (Jensen, 2001; Jensen and Murphy, 1990). However, when compensation schemes are excessively tied to stock prices, managers tend to concentrate their efforts on managing market expectations instead of running their companies in order to create real value. Martin (2011) sums up this criticism by saying that "expectations are where the money is" (p. 27) $)^{54}$

A recent case in Brazil illustrates this problem. Between 2007 and 2010, high-profile entrepreneur, Eike Batista, launched six different companies at the Brazilian stock market. The backbone of the conglomerate was OGX, an oil firm that raised US\$4.1 billion at its strongly demanded IPO in June $2008^{55}$. The company had been created just one year before on the promise of great exploration prospects. After announcing several oil discoveries, OGX market capitalization peaked around US\$40 billion in September 2010. The company, however, started to fall far short of expectations regarding its oil production. It started by postponing pumping its first expected oil from 201 to the following year. In June 2012, it slashed production guidance for its allegedly most valuable oil field. Stock price started a downward trend after becoming increasingly clear that

${ }^{54}$ In addition, linking top executives' pay to stock prices may lead to excessive risk-taking and less emphasis on environmental and social aspects in decision-making. Martin (2012) provides a deep discussion on this issue.

${ }^{55}$ OGX's were sold at US\$ 690 per share at its initial public offering, the top of the established price range. Around 50,000 institutional and retail investors bought OGX stocks (foreign institutional investors acquired around two-thirds of the shares). At the time, it was the biggest IPO in Brazilian history. The company was listed at Novo Mercado, the premium listing segment that requires stricter corporate governance standards. ${ }^{56}$ At its peak in the first half of 2013, the firm's oil production reached 8,500 barrels a day, less than one fifth of the level predicted in the IPO prospectus.

${ }^{57}$ At that point, the company owed US\$ 3.6 billion in bonds and US\$500 million to suppliers, making it Latin American largest corporate failure. Sources: Financial Times. Eike Batista's empire crumbles as talks with OGX creditors fail. October 29th 2013. Available at http://on.ft.com/1coEOYt; Reuters. Batista's OGX files for bankruptcy protection in Brazil. October 30th 2013. Available at http://www.reuters.com/article/2013/10/30/ us-brazil-batista-idUSBRE99T19620131030; The Economist. Butista: Eike Batista's oil firm files for bankruptcy protection. the company would never produce near expectations ${ }^{56}$. Earlier in 2013, OGX announced ceasing the production of several oil fields, including its most valuable one, because they were commercially unviable. On October 30th 2013, OGX finally filed for bankruptcy protection under a US\$4.1 billion debt load ${ }^{57}$. Its stocks fell $99 \%$ while bonds were traded at $8 \%$ of face value.

The OGX collapse, without generating any positive economic value, though, did not prevent its senior executives to pocket millions due to equity-based arrangements exercised during the brief period in which its shares remained at a high level. At least ten senior officers cashed between US\$35 and US\$100 million from compensation schemes based on stock-option plans ${ }^{58}$, while dozens of others lower level executives pocketed between US\$1 and US\$35 million. One C-level executive (that was neither the CEO or CFO), for instance, cashed around US\$55 million during the short period of 30 months in which he worked for the company ${ }^{59}$. Ironically, the Investor Relations officer quit the company two months before the most important announcement of its history in June 2012, when OGX informed the market that its reserves were far smaller than expected. He sold all his shares in the two months before this announcement, earning around US\$60 million during his five years' tenure ${ }^{60}$.

A somewhat similar tale on the side effects of equity-based pay also occurred with executives from financial institutions

November 2nd 2013. Available at http://www.economist.com/ news/business/21588903-eike-batistas-oil-firm-files-bankruptcy-protection-bustista.

58 Until November 2009, OGX stock-option plan required a lock-up period of 36 months. In that month, the company simply extinguished this clause, allowing its executives to immediately exercise their stock options and pocket millions of dollars. Incredibly, this major change was not announced to the market at the time. Source: Exame magazine (in Portuguese). Todos os homens de Eike. March 19th 2014. Available at http://exame. abril.com.br/revista-exame/edicoes/1061/noticias/todos-oshomensde-eike

59 Source: Exame magazine (in Portuguese). Todos os homens de Eike. March 19th 2014. According to the publication, the executives pocketed between $\mathrm{R} \$ 70$ and $\mathrm{R} \$ 200$ million. The conversion to US\$ was made at an exchange rate of $\mathrm{R} \$ 2.00 / 1$ US\$, the average rate from 2008 to 2012.

60 Source: Exame magazine. According to the publication, executives sold "everything they could" in the two months before the key announcement of far shorter reserves. It is estimated that they have sold around 17 million of shares during this brief period, pocketing around US\$ 95 million. 


\section{REVIEW \\ OF GLOBAL \\ MANAGEMENT}

FACULTAD DE

NEGOCIOS

UPC

that collapsed in 2008. While economic value generated by these banks to its longer-term shareholders was obviously null, their executives cashed several hundred million dollars while stocks were overvalued.

The argument that equity-based pay induces executives to excessive risk-taking in their quest to please stock markets and pocket astronomical compensation is supported by empirical evidence ${ }^{61}$. Fahlenbrach and Stulz (2011), for instance, find that banks with CEOs whose incentives were better aligned with the interests of shareholders in terms of the dollar value of their stake performed worse during the crisis ${ }^{62}$. DeYoung et al. (2013) also note that large U.S. commercial banks increased the equity-based incentives of its CEOs around the year 2000, and that executives responded by increasing banks' business policies as well as risk-taking ${ }^{63}$.

Creating executive compensation schemes that are heavily dependent on something that is inherently speculative and dependent on the formation of beliefs, such as stock prices, is, therefore, very dangerous. It generates pressure towards "game the game"64 through strategies ranging from the use of legal forms of earnings management ${ }^{65}$ to fraud 66

${ }^{61}$ In this sense, Bratton and Whatcher (2010) point out that "The financial sector undertook high-risk/high-return strategies to enhance return on equity and raise stock prices. The executives who danced to the rhythm were compensated with stock options and restricted stock in addition to cash bonuses, and so had incentives roughly in alignment with those of their shareholders" (p. 723).

${ }^{62}$ According to Fahlenbrach and Stulz (2011), "A plausible explanation for these findings is that CEOs focused on the interests of their shareholders in the build-up to the crisis and took actions that they believed the market would welcome. Ex-post, these actions were costly to their banks and to themselves when the results turned out to be poor... CEOs might have concluded that they had no choice but to focus on short-run profit maximization because they feared losing their job had they not grown their banks' business aggressively" (p. 12).

${ }^{63}$ The final report of the U.S. Government Financial Crisis Inquiry Commission also recognized the reckless behavior induced by equity-based pay by concluding that "Too many of these institutions acted recklessly, taking on too much risk, with too little capital, and with too much dependence on short-term funding. Compensation systems too often rewarded the quick deal, the short-term gain without proper consideration of long-term consequences. Often, those systems encouraged the big bet - where the payoff on the upside could be huge and the downside limited. This was the case up and down the line - from the corporate boardroom to the mortgage broker on the street".

64 This expression is used originally by Martin (2011).

${ }^{65}$ Positive results, for instance may be delayed as a sort of
Moreover, a recent behavioral literature summarized by Stout (2014), shows how pay-for performance-strategies may lead to counterproductive and potentially disastrous outcomes for the governance of complex human organizations such as public companies.

Stout (2014) points out that ex-ante incentive schemes such as equity-based pay may lead to at least three adverse behavioral consequences. First, they tend to frame the social context in a way that encourages people to conclude that purely selfish behavior is both appropriate and expected. Second, the possibility of large personal rewards may tempt people to cut ethical and legal corners. Third, firms that emphasize incentive pay tend to attract individuals who are more prone toward selfish and opportunistic behavior than the average, while inducing current employees to start acting in a more purely self-interested way ${ }^{67}$. She argues that: [Pay] for performance creates very big temptations... Incentive contracts based on metrics subject to executives' influence, especially metrics that executives can manipulate or falsify, create tempting opportunities for executives to try to extract this wealth for themselves through behavior that imposes costs on the corporation or on third parties. Thus a workplace that relies on large material incentives to motivate employees is also a workplace

provision for other periods, while important spending may be cut and losses distorted in order to do not affect quarterly results.

${ }^{66}$ Martin (2011) points out that the "expectations management" puts managers in a dilemma. If the company is doing well and operating at peak performance, stock markets will immediately incorporate in the stock price the expected future maximum performance. In this case, how executives would be able to raise stock prices even further? Since the shareholder value doctrine requires executives to increase stock prices continuously, they would need to raise market expectations about the company infinitely. This requires, therefore, an impossible mission from executives: to raise other's people expectations continuously and forever (Martin, 2011, p. 193).

${ }^{67}$ According to Stout (2014): "the end result may be not more efficient behavior, but more uncooperative, unethical, and illegal employee behavior". As a solution, she recommends trust-based compensation arrangements emphasizing rewards that are modest, nonmonetary, and awarded ex-post on a discretionary basis. She points out, that the use of fixed salaries with occasional modest bonus, both adjusted ex post on the basis of subjective criteria, was the typical form of payment for executives of U.S. public companies until the early 1970s: "You did a great job this past year, we're giving you a bonus and a raise". Dorff (2014) points out to a somewhat similar solution by arguing that directors should tie senior officers' payments to factors that are "(a) largely within officers' control, (b) hard to manipulate, (c) easy to measure, and (d) important to the corporation's long-term goals" (p. 1). 
that suppresses the force of conscience (p. 33)

Extrinsic motivations such as stock options plans, therefore, may "crowd out" managers' innate internal desire to perform their roles properly (Gneezy et al., 2011) ${ }^{68}$. Undermining intrinsic motivation is problematic because people tend to lose interest in their work once extrinsic factors are no longer offered. As a result, extrinsic rewards should be permanently offered to managers as motivation to sustain their activity.

Finally, there is also evidence that excessive and contingent monetary rewards may even result in a decline of performance, especially in cognitively complex activities. This is the main conclusion of Ariely et al. (2009), after conducting extensive experiments in the U.S. and India, in which subjects received performance payments in varying amounts across multiple tasks. The authors observe that performance is superior for moderate economic incentives, but it then starts to fall beyond a certain threshold level. The idea that higher monetary rewards may lead to worse performance is also the subject of recent neuroscience literature, such as in Chib et al. (2014) and Atchziger et al. (2015).

\section{INCREASED INCOME INEQUALITY WITHIN FIRMS AND AT THE MACRO LEVEL}

In addition to its numerous side effects presented in the previous section, equity-based pay has skyrocketed top-executive compensation in Anglo-Saxon countries in the past thirty years, without a correspondent enhancement of firms' performance (Bebchuk and Grinstein, 2005; Lazonick, 2009a; Dorff, 2014) ${ }^{69}$. This has led to increasing

\footnotetext{
68 The reduction in intrinsic motivation due to an excess of external rewards is a phenomenon also known as the overjustification effect. ${ }^{69}$ It is important to note that managerial pay increased even without a clear improvement in the performance of corporations on an aggregate basis.

70 There is a huge literature pointing out to the negative economic and social impacts deriving from higher economic inequality. Among other problems, countries with greater economic inequality exhibit lower levels of economic growth, lower life expectancy, higher level of violence, stress, mental disorders, etc.

${ }^{71}$ After decomposing the top decile into three groups, Picketty and Saez (2006) observe that most fluctuations are due to fluctuations within the top $1 \%$ percentile

72 The concentration of income at corporations can be observed by the evolution of CEO pay relative to worker pay in the U.S. According to the Economic Policy Institute, it climbed from around 25 in 1970 to around 300 in 2010.
}

levels of income inequality at both the firm and the society-level, an outcome related to an array of negative social implications, such as higher levels of stress, violence, health problems, and economic capture of democratic institutions ${ }^{70}$. According to Piketty and Saez (2006), the income share of the top decile in the U.S. from 1980 until 2002 returned to the record levels observed before World War I in $1917^{71}$. They also note that, until the 1970s, highest incomes in the U.S. were composed primarily of capital income (mostly dividends). Afterwards, salary income has been driving up top incomes, becoming nowadays the main source of income (and of economic inequality) at the very top ${ }^{72}$.

In a cross-country comparison, Piketty and Saez (2006) identify a major divergence: while top income shares have remained fairly stable in continental Europe and Japan since the 1970s, they have increased enormously in the U.S. and other English-speaking countries. In their view, [This] rise of top income shares is due not to the revival of top capital incomes, but rather to the very large increases in top wages (especially top executive compensation). Top executives replaced top capital owners at the top of the income hierarchy during the twentieth century (p. 204) ${ }^{73}$. More recently, Saez (2013) shows that the trend towards income concentration in the U.S. continues after the 2008 global financial crisis. According to the author, the top 1\% incomes grew by 31.4\% from 2009 to 2012, while the bottom $99 \%$ incomes grew only by $0.4 \%^{74}$. In his view, the Great Recession has only depressed top income shares temporarily and will not undo any of the dramatic increase in top income shares that has taken place since the 1970s. Indeed, the top decile income share in 2012 is equal to 50.4\%, the highest ever since 1917 when the series start (p. 1) ${ }^{75}$.

\footnotetext{
73 The authors point out that understanding why top wages have surged in English-speaking countries in recent decades but not in continental Europe or Japan is a very controversial topic. One strand argues that technological progress has made managerial skills more general and less firm-specific, increasing competition for the best executives from segregated within-firm markets to a single worldwide market. (If this is true, then impediments to free markets due to labor market regulations or social norms regarding pay inequality should have kept executive pay below market in markets outside the Anglo-Saxon world). The other strand, in turn, points out that the surge in top compensation in the U.S. is due to the increased ability of executives to set their own pay and extract rents at the expense of shareholders.

74 The top 1\%, therefore, has captured 95\% of the income gains in the first three years of the recovery.

${ }^{75}$ Lin and Tomaskovic-Devey (2013) show that, for full-time
} 


\section{REVIEW}

OF GLOBAL

MANAGEMENT

FACULTAD DE

NEGOCIOS

UPC

Research in the field of sociology of organizations explain how the rise of shareholder value orientation has increased economic inequality through the restructuring of social relations and income dynamics in the organizational setting. Shin (2012), for example, shows how portraying yourself as a supporter of shareholder value pays off for executives. He reaches this conclusion after analyzing the relationship between orientation to this doctrine and financial rewards for 290 CEOs for the 1996-2006 period. He observes that compensation is greater in firms with a stronger display of shareholder value orientation than in non-shareholdervalue firms. Moreover, he notes that when firms strengthen their appearance of shareholder value orientation by enhancing monitoring and incentive pay system, CEO pay increases the subsequent year ${ }^{76}$. His interpretation is that firms adopt monitoring and incentive-alignment mechanisms symbolically, only to signal investors their conformity with its principles. This, in turn, increases managers' legitimacy, leading to an increased in their compensation regardless of their performance. In his words: [Even] though the shareholder value ideology was initially proposed to curb managerial power, it may have paradoxically provided powerful managers with a symbolic and rhetorical tool for accumulating personal wealth. This may explain a significant part of the rise in CEO compensation (p. 554).

Hanley (2011), in turn, investigates the sources for the growth of high-wages and rising inequality in the workplace. She finds that earnings associated with high-wage occupations vary across industry groups depending on the prevalence of performance pay practices ${ }^{77}$. She notes that "pay initiatives tying individual earnings to measures of company performance such as shareholder value increase managers' earnings, independent of their particular skills" (p. 903). As a result, she concludes that pay initiatives rewarding a small class of workers probably serves as the main mechanism for high-wage earnings growth and rising inequality.

The connection between financialization (one of the

workers, the Gini index of earnings inequality increased 26\% between 1980 and 2007 in the U.S. They also point out income inequality in the U.S. is now equivalent to that of developing countries such as Iran, China, and Mexico.

${ }^{76}$ According to Shin (2012), "Shareholder value mechanisms did not curb the surge of pay; rather, it preceded the CEO pay raise" (p. 538)

${ }^{77}$ Interestingly, she also observes that low-wage occupations do not vary across industry groups.

${ }^{78}$ Their results are obtained net of other factors conventionally pointed as causes of higher income inequality, such as de- consequences of the cult of shareholder value) and rising income inequality in non-financial companies is the subject of two recent papers. Lin and Tomaskovic-Devey (2013) analyses this issue for several U.S. industries from 1970-2008. They find that, in the long run, increasing dependence on financial income is associated with reducing labor's relative income; increasing top executives' relative compensation; and increasing earnings dispersion among workers ${ }^{78}$.

Financialization accounts for more than half of the decline in labor's share of income; $9.6 \%$ of the growth in executives' fraction of compensation; and $10.2 \%$ of the growth in earnings dispersion between 1970 and 2008. In their view, the institutional shift since the 1980s from managerialism to the shareholder value conception of the firm is at its core a system of redistribution that has privileged a limited set of actors ${ }^{79}$. Alvarez (2015), in turn, finds a similar result after analyzing 6,980 non-financial firms from 2004 to 2013 in France. He concludes that increased dependence on financial profits is likely to decrease wage share in non-financial French companies. In his view, the growing involvement of non-financial companies in financial markets has increased financial profits, which in turn has resulted in less bargaining power for employees relative to shareholders and managers.

\section{OPPORTUNISTIC BEHAVIOR OF SHAREHOLDERS SEEKING SHORT-TERM GAINS IN MEAS}

This critique derives from the Blair and Stout (1999) team production theory. Their theory explores the economic importance of firm-specific investments made by stakeholders for organizations to succeed. In this sense, all stakeholders-especially employees, suppliers and local communities-make specific investments that goes far beyond what their contracts require ${ }^{80}$. If some shareholders could profit from opportunistic strategies that threatens the value of

unionization, globalization, technological change, and capital investment.

${ }^{79}$ According to Lin and Tomaskovic-Devey (2013), we believe that firms' increasing reliance on financial, rather than production, income decoupled the generation of surplus from production and sales, strengthening owners' and elite workers' negotiating power against other workers. The result was an incremental exclusion of the general workforce from revenue-generating and compensationsetting processes (p. 1285).

80 This specific-firm investments are of course not fully protected by formal contracts. 
other stakeholders' specific investments, then stakeholders would be discouraged to make firm-specific investments in the first place. In order to avoid this bad outcome for all constituencies (including long-term shareholders) companies should create mechanisms to avoid actions from opportunistic stockholders.

Mayer (2013) develops a similar criticism focusing on the dangers of an open market for corporate control. He argues that companies are a mechanism to sustain long-term commitments among different stakeholders and that these implicit or explicit commitments will only work if it is costly to other parties to act opportunistically. His point is that such commitment cannot be sustained with an active market for corporate control because shareholders, especially those short-term oriented, will be tempted to act opportunistically by selling the company anytime when an opportunity of quick returns arises. When it is sure that shareholders will act opportunistically, the corporation becomes "a rent extraction vehicle for the shortest-term shareholders" (Mayer, 2013, p. 240). and aligning managerial rewards to shareholder returns will only reinforce this opportunism $^{81}$.

The hostile takeover of Cadbury, a British corporate icon with over 200 years, by U.S. Kraft in 2010 is considered a classic case highlighting this problem. On September 7th 2010, the buyer offered $£ 7.45$ per share, a $30 \%$ premium above the stock price at the time ${ }^{82}$. After hiring outside advisors and reviewing the proposal, Cadbury's board concluded that it was derisory ${ }^{83}$. Without managers' support, Kraft initiated the hostile takeover attempt by sending a letter of intent directly to Cadbury shareholders.

Speculation about the ongoing operation increased Cadbury's stock to around £8.00. The stock's appreciation prompted a change in the profile of shareholders that would determine the outcome of the takeover. Before the

\footnotetext{
81 There is an extensive literature on takeovers that goes far beyond the scope of this paper. On average, it shows that shareholders from target companies usually benefit form an active market of corporate control, while the outcomes for shareholders of acquiring firms are mixed (being more likely to earn negative rather than positive stock returns). In addition, stakeholders from target companies (especially employees) usually suffers negative impacts from these operations.

82 The offer totaled $£ 10.2$ billion paid $60 \%$ in stocks and $40 \%$ in cash.

${ }^{83}$ The board decided that any offer below $£ 8.50$ (a 50\% premium on the stock price before Kraft's offer) would not be recommendable. In the end, this was precisely what Kraft offered for the operation to succeed.

84 "Cadbury: Hostile bids and takeovers". University of Oxford -
}

offer, short-term traders held about $5 \%$ of its shares. Several hedge funds then started to buy shares in the expectation of making quick gains from the operation. On the other side, long-term shareholders sold a part of their holdings to enhance their portfolios' return (a process called "top slicing"). Throughout 19 weeks, $26 \%$ of the shares passed into the hands of short-term oriented hedge funds, which ended up with $31 \%$ of the Cadbury's stock.

In a lecture about the takeover, Roger Carr, former Chairman of Cadbury's board, summed up the unfolding of case ${ }^{84}$ : [The] fate of the company was sealed long before the final act. It was determined more by the significant changes which have taken place in the share register during the bid period. That had more effect than any other event... Hedge funds were buying only for the short-term profits. Their activity increased along with the likelihood of the transaction occurring. In other words, if they could buy enough shares, the deal would become a self-fulfilling prophecy... It was the interests of this ownership profile at the end of the process that the board was representing when it agreed with the final offer of $£ 8.50$. Since most hedge funds had acquired shares below $£ 8.00$, we knew the battle for independence was lost [when Kraft revised its offer to $£ 8.30$ ] because the majority of our shareholders would have sold out for this price, or even less. [In this case,] most of the short-term shareholders would earn a profit of about $£ 0.30$ per share for holding the stock for just about six weeks, an annualized gain of $33 \%{ }^{85}$. So, in pursuit of shareholder value the task became clear, however personal unpalatable: it was to negotiate for the best price posible for our shareholders. Fiduciary duty had to overcome emotional instinct. In the final analysis, it was the shift in the share register that lost the battle for Cadbury. The owners were progressively not long-term stewards of business, but financially motivated investors judged solely on the quarterly financial performance. At the end of the day, there were simply not enough shareholders prepared to

Distinguished Speaker Seminar Series from the Said Business School. Available at https://podcasts.ox.ac.uk/roger-carr-cadbury-hostile-bids-and-takeovers

${ }^{85}$ Actually, since the final offer was $£ 8.50$, most hedge funds earned an annualized return of around 50\% for holding Cadbury's shares for a few weeks. As usual in other takeovers, the outcome was far from bright for other stakeholders of the target company. When Kraft announced its initial offer, CEO Irene Rosenfeld stated "our current plans contemplate that the UK would be a net beneficiary in terms of jobs. For example, we believe we would be in a position to continue to operate the Somerdale facility, which is currently planned to be closed, and to invest in Bournville, thereby preserving UK manufacturing jobs" (Source: Clarke, 2010). One week after concluding the deal, though, Kraft announced 
take a long-term view of Cadbury and prepared to forego short-term gain for longer term prosperity. ${ }^{86}$ This is the clear message: individuals controlling shares which they held only for a few days or weeks determined the destiny of a company that have been built over almost 200 years. ${ }^{87}$

The Cadbury takeover demonstrates the danger of opportunistic behavior from short-term oriented shareholders when they become decisive for key corporate decisions, especially in companies with dispersed ownership structures ${ }^{88}$. It also shows how the (questionable) belief, ingrained among directors, that they should maximize shareholder value may lead to potentially harmful decisions for other stakeholders and of the company in the long run.

Interestingly, the episode also reveals the difficulty of properly interpreting the view that directors should owe fiduciary duties solely to shareholders when their profile and preferences change substantially in a few weeks. In Cadbury's case, the shareholder base composed primarily of institutions interested in the long-term success of the company at the beginning of the takeover process was sharply transformed into one with a strong presence of short-term investors seeking quick gains. The shareholder value precept, therefore, overlook the fact that shareholders

the closure of its centennial Somerdale factory of Cadbury and the transfer of its activities to Poland.

${ }^{86}$ Carr also notes that "The short-term players that obtained the pivotal position in determining the outcome by accumulating shares from long term funds also hedged their bets at the same time in case the bid failed and the share price fell back".

${ }^{87}$ It is very interesting to note that, although Carr raises concerns about current takeover rules in the British market from a wider perspective, he himself admits being an advocate of shareholder value whose career has been built in a platform of M\&A activity: "By instinct, because of my career, I am a complete free marketer. I do not believe in protectionism or safe harbors. I do believe very strongly in open markets, shareholder value, management challenge, the role of hedge funds, constant pressure from competition and the threat of corporate activity... A hostile takeover requires a passionate believe in the cause that you are fighting. And the cause is the value it creates for shareholders. In execution [of the takeover defense], there are four golden rules to remember. One, you are fighting for shareholder value, and only value..." (emphasis added). For more about Cadbury's case, see Clarke (2010) and Tsagas (2014).

${ }^{88}$ For Mayer (2013), trust is an essential element for people to engage into long-term contracts and it is paramount avoiding companies to behave opportunistically. In an article commenting on Mayer's book, Financial Times Columnist points out "But, a company whose goal is whatever seems profitable today constitute a heterogeneous block with different interests and time horizons ${ }^{89}$.

\section{INCREASED JOB INSECURITY, STRESS, AND LACK OF PURPOSE IN THE ORGANIZATIONAL ENVIRONMENT}

As noted in the previous section, the long-term success of a company depends on the collective effort of all its stakeholders. This, in turn, usually requires them to make firm-specific and-non recoverable investments in the organization (Blair and Stout, 1999; Mayer, 2013).

To critics, the obsession with shareholder value maximization reduces companies' commitment towards its stakeholders by converting them into disposable and interchangeable resources ${ }^{90}$. The relationship with stakeholders becomes increasingly dehumanized, fostering an organizational atmosphere with higher levels of stress, anxiety, and aggressiveness, as well as less sense of purpose and engagement.

The interesting case of the multinational brewery Ambev, considered the poster boy of shareholder value

can be trusted only to renegade implicit contract". Source: Opportunistic shareholders must embrace commitment. Financial Times. August 26th, 2014. Available at http://on.ft. com/1nywFGb

${ }^{89}$ Stout argues that the standard shareholder-centered model has favored short-term speculators over long-term investors. According to the autor "Activist hedge-funds have the clear advantage, because they concentrate their investment portfolios into just a few securities. This means it is worth their while to spend the time and effort necessary to become involved in a particular firm's affairs. Diversified retail investors, by contrast, rarely have a big enough stake in any single company to make it sensible to closely monitor what's going on; they suffer from their own rational apathy. Mutual funds are not much better. Most fund managers rationally conclude it is not in their client's best interests for them to exercise an active governance in the hundreds of firms whose stocks the fund manager keeps in his portfolio" (p. 70). For more studies on the effects of shareholder activism, see Kahan and Rock (2007), Anabtawi and Stout (2008), Betch et al. (2009), Brav et al. (2009), Bratton and Wachter (2010), Yermack (2010), and Cheffins and Armour (2011). 90 It is important to note that the pressure for stock price maximization can be divided in two stages that end up harming stakeholders. First, market agents pressure managers to adopt business practices aiming to promote shareholder value. Second, managers tend to divert this pressure onto stakeholders, particularly on employees. 
in the Brazilian market, provides anecdotal evidence supporting this criticism. The company is controlled by a group of three entrepreneurs ${ }^{91}$ who owns a private equity firm (3G Capital) which is laser-focused on maximizing earnings. According to Fortune Magazine, "the cutthroat Brazilian private-equity firm is known for swift layoffs, cost-cutting - and profit"92, whereas Financial Times emphasizes its "ruthless operating focus"93.

Ambev adopts economic value added, one of the tenets of the shareholder value movement, as its performance measure since the late 1990s. In its 2002 Annual Report, for example, the company reported: "our target is to grow the Economic Value Added (EVA) at a minimum of 15\% a year in real terms with a $20 \%$ return on equity (ROE)" 94 . Its incentive system is strongly based on massive stock option plans for both its executives as well as for board members ${ }^{95}$. Variable compensation (not counting stocks and stock option plans) represented around 70\% of the total executive compensation in 201496. From 2011 to 2013, its CEO pocketed around R \$ 18 million (US\$ 6 million) per year without accounting for equity-based payments, while its Chairman earned around $\mathrm{R} \$ 9$ million per

91 Jorge Paulo Lemann, Marcel Telles e Beto Sicupira.

92 Fortune Magazine. "Here's what happens when 3 G Capital buys your company". March 25th 2015. Article by Daniel Roberts. Available at http://fortune.com/2015/03/25/3g-capital -heinz-kraft-buffett/. The 3G Fund usually implements an accounting technique known as zero-based budgeting as part of their corporate strategy. This scheme compels divisions to justify all costs for each year, rather than simply adjusting the baseline spending from the previous year. One of the favorite phrases of Mr. Sicupira, one of the partners, is that "costs are like fingernails: You have to cut them constantly." Source: Time Magazine. Bud Brewer Braced for Change. July 15th 2008. Available at http://content.time.com/time/business/ article/0,8599,1822811,00.html

${ }^{93}$ Financial Times. "Ruthless operating focus behind $3 \mathrm{G}$ rise". March 25th 2015. Available at http://www.ft.com/intl/cms/s/O/ a7fcbc1a-d30c-11e4-a792-00144feab7de.html\#axzz3YoCYtIlC. For understanding Ambev's management style, see also: Financial Times. "Jorge Paulo Lemann, a lean, hungry mogul". March 27th 2015. Available at http://www.ft.com/intl/cms/s/O/ ad85be00-d2ff-11e4-b7a8-00144feab7de.html\#axzz3YoCYtIlC.

${ }_{94}$ Ambev Annual Report 2002. English version available at http://media.corporate-ir.net/media_files/nys/abv/reports/ AR_AmBev_2002.pdf

${ }^{95}$ In 2014, 680 Ambev managers held stock options of the company. The plan of equity-based compensation is administered by the board of directors, who is at the same time one of its beneficiaries. Source: Reference Form 2014. year ${ }^{97}$. The company is widely recognized in Brazil for its aggressive corporate culture ${ }^{98}$, to the point that it has launched a public relations campaign to show its "less aggressive" side to society in $2010^{99}$

One of the (predictable) results of Ambev's shareholder -driven culture are the complaints from several of its stakeholders about its ruthless behavior and lack of long-term commitment. After taking over the Belgian company Interbrew, for instance, the local union argued that it broke promises by carrying out plant closures, layoffs, and changes in work rules. According to one union leader "I wouldn't trust their promises...InBev is all about money... Before it was run by brewers, but now it's [by] bankers" 100.

The company has also been subject to several lawsuits in the Brazilian courts for bullying and psychological harassment filed by its former employees ${ }^{101}$. Among the bizarre situations reported in these lawsuits are cases of employees subjected to several punishments in case of not meeting their goals, such as: i) doing push-ups until exhaustion with the boss stepping on his back ${ }^{102}$; ii) lying in coffins while being portrayed as chickens hanged in the

96 Source: Reference Form 2015. Section 13. Available at http:// ri.ambev.com.br/

${ }^{97}$ For comparison purposes, Ambev's CEO and Chairman compensations represent 1,256 and 718 times the annual compensation of the average Brazilian worker, respectively. ${ }^{98}$ As an example of this its aggressiveness culture, it is reported the tables of Ambev's in-company MBA course for its highpotential executives are filled with red fabric tomatoes. Each time the lecturer or a student says something considered foolish, the students throw tomatoes towards on him or her. Source. Revista Exame. "Bônus, tomates e patos. December 12th 2000. Available at http://exame.abril.com.br/revista-exame/ edicoes/729/noticias/bonus-tomates-e-patos-m0047822 99 Folha de São Paulo. "AmBev faz campanha para mostrar lado "menos agressivo". July 23rd 2010. Article by Mariana Barbosa. Available at http://www1.folha.uol.com.br/fsp/mercado/ me2307201009.htm

100 Source: Time Magazine. Bud Brewer Braced for Change. July 15th 2008. Available at http://content.time.com/time/business/ article/0,8599,1822811,00.html. In 2009, Ambev also received a record fine of BRL 350 million from Brazilian authorities for harmful and unfair competition in the beer market. Source: Valor Econômico. Cade aplica multa recorde de R\$352,7 milhões a Ambev por concorrência desleal. July 22nd 2009.

${ }^{101} \mathrm{~A}$ more detailed description of these cases is available at ERA (Ética e Realidade Atual): http://era.org.br/2011/10/am bev- assedio-moral-e-baluarte-de-estilo-vitorioso/

102 Case AIRR 1370/2005-006-20-40.0 from 6a Turma do Tribunal 


\section{REVIEW \\ OF GLOBAL \\ MANAGEMENT}

FACULTAD DE

NEGOCIOS

UPC

meeting room ${ }^{103}$; iii) being forced to wear skirts, lipstick and helmets with horns ${ }^{104}$; iv) going through a "polish corridor"105 while hearing insults from their managers ${ }^{106}$; v) being forbidden to sit during meetings ${ }^{107}$; and, vi) being obliged to dance in front of others while wearing t-shirts with offensive sayings 108 .

Ambev's legal problems have not been confined to its unorthodox punishments. Its incentive system has also been subject to lawsuits. In one case, for instance, a former employee sued the company for being obliged to attend morning events in which prostitutes performed stripteases as part of "motivational" sessions to increase sales ${ }^{109}$. In other case, one of the supervisors used to gunshot competitor's logo in order to "incentivize" employees ${ }^{110}$.

There is also broader evidence supporting the criticism that the lack of long-term commitment resulting from shareholder value maximization lead to poorer organizational environments. A 2014 Gallup poll, for instance, concluded that only $35 \%$ of U.S. managers are engaged in their jobs, while $51 \%$ are not engaged and $14 \%$ are actively disengaged ${ }^{111}$. The figure for lower level employees is even most impressive, demonstrating that "of the country's roughly 100 million full-time employees, an alarming 70

Superior do Trabalho de Sergipe. Available at http://www.conjur. com.br/2006-dez-18/ex-empregado_ambev_indenizacao_danos ${ }^{103}$ Case RR-32100-53.2006.5.04.0101, 2a Turma do TST do Rio Grande do Sul. Available at http://economia.estadao.com.br/ noticias/geral,ambev-tera-de-indenizar-ex-funcionario-por-dano -moral,53717e

${ }^{104}$ Case RR 985/2006-025-03-00.7 3a turma Tribunal Superior do Trabalho de Minas Gerais. Available at http://www.direitonet. com.br/noticias/exibir/11479/Ambev-e-condenada-por-usarassedio-moral-para-aumentar-produtividade

${ }^{105} \mathrm{~A}$ "polish corridor" is a form of punishment in which the person has to go through a group of people aligned in two lines facing each so that they form a "corridor". During the passage, the person receives slaps and other forms of physical abuse from the people who formed the corridor.

${ }^{106}$ Case n ${ }^{\circ}$ 00887/2003-015-04-00, 8a Turma do Tribunal Regional do Trabalho da $4^{a}$ Região do Rio de Janeiro. Available at http://www.conjur.com.br/2004-ago-17/ambev_condenada_submeter_empregado_humilhacoes

${ }^{107}$ Case TRT 6a Reg., Proc. № 00340-2004-005-06-00-1 available at http://www.conjur.com.br/2006-ago-23/ambev_pagar_mil-

hao_assedio_moral_coletivo

${ }^{108}$ In another case, Ambev was condemned to pay BRL 1 million in a collective psychological harassment case involving dozens of workers punished for not meeting their sales goals. Case TRT $6^{a}$ Reg., Proc. No 00340-2004-005-06-00-1 available at http:// www.conjur.com.br/2006-ago-23/ambev_pagar_milhao_assedio_ moral_coletivo million (70\%) are either not engaged at work or are actively disengaged"112.

Gallup estimates that this lack of engagement costs between $\mathrm{U} \$ 450$ billion to $\$ 550$ billion in lost productivity per year for the economy. Interestingly, among the twelve items used to measure the level of engagement, the institution concludes that one of the two most important questions that lead to higher engagement is "The mission or purpose of my company makes me feel my job is important". As a result, it is possible to conjecture that companies with the uninspiring mission of maximizing profits, as prescribed by the shareholder value approach, naturally tend to fare worst in this item ${ }^{113}$

Research in the field of sociology of organizations and political economy also presents a dramatic picture linking the rise of the shareholder value movement in the 1980s to the disintegration of the postwar business-labor social contract in developed countries, leading to increasing job insecurity and declining working conditions.

In one of the earlier studies on this field, Budros (1997) examines the causes of the adoption of downsizing programs among Fortune 100 firms from 1979 to 1994114.

${ }^{109}$ According to court documents, the "employee of the month" received the right to choose one of the prostitutes for his personal pleasure as an award (all paid with company resources). The employee who sued the company claimed to suffer psychological problems due to conflicts with his religion. Case RR-3253900-09.2007.5.09.0011. 5a turma do TST do Paraná Available at http://www.istoedinheiro.com.br/noticias/negocios/20120914/sexo-cerveja-bonus-ambev/102465.shtml 110 Case AIRR 1370/2005-006-20-40.0 from 6 ${ }^{a}$ Turma do Tribunal Superior do Trabalho de Sergipe. Available at http://www.conjur. com.br/2006-dez-18/ex-empregado_ambev_indenizacao_danos 111 Gallup interviewed 2,654 managers from diverse industries. Source: Gallup. 2014. State of the American manager: analytics and advice for leaders. Available at http://www.gallup.com/ services/182138/state-american-manager.aspx 112 Source: http://www.gallup.com/opinion/chairman/169208/ millions-bad-managers-killing-america-growth.aspx 113 It is also worthy to note that this strikingly low engagement level in the U.S. has been stagnant since 2000, when Gallup began tracking this indicator.

114 The author has been of one of the first to argue that a "new capitalism" has emerged in the U.S. since 1980. He also notes that, before the 1980s, managers engaged in downsizing only reluctantly because expanding the size of the firm was the hallmark management. Afterwards, downsizing has become as a strategy to manage shareholder value by signaling investors the managerial commitment to increase stock value. 
He finds that the orientation toward shareholder value is one of the main predictors of downsizing decisions ${ }^{115}$. He also observes that, while firms are supposed to make personnel cuts for economic reasons, the outcomes of these cuts generally are negative. As a result, he concludes that "[Even] though the economic rationality of downsizers seems limited, the analysis also discloses that downsizers are motivated by noneconomic factors - especially social acceptance of downsizing - and that they receive noneconomic rewards - especially favorable reputations - for their actions" (p. 247). In other words, organizations are motivated by economic as well as social considerations, and both forms of rationality are needed to fully explain downsizings.

Fligstein and Shin (2007) use data from 62 U.S. industries for the 1984-2000 period to analyze the impact of shareholder value strategies, such as mergers and lay-offs, on unionization and profitability. In line with shareholder value arguments, they observe that industries where mergers were active subsequently saw an increase in layoffs. However, contrary to shareholder value arguments, there did not find evidence that mergers or layoffs returned industries to profitability. They conclude by arguing that "shareholder value tactics to reorganize firms and industries failed in their central goal - to increase profits"116

Jung (2015) also studies how the shareholder-value paradigm has contributed to the prevalence of widepread lay-offs since the 1980s by investigating downsizing announcements from 714 US firms between 1981 and 2006. He finds that both the pressure from institutional investors and the new decision context for managers' behavior provided by the rise of shareholder value encourage firms to downsize more frequently. The new managerial "decision context" can be observed, according to the author, by indicators such as the granting of stock-option plans; the level of board independence; and the presence of the CFO on the board of directors.

Jung (2015) also provides three examples of how even firms with good economic performance opt to downsize as part of a shareholder-value strategy (p. 1338). In 1997 , Kimberly-Clark eliminated 5,000 jobs in a bid to push the company closer to achieving management's goal of doubling earnings per share between 1995 and 2000. In 2000, Dell Computer, after failing to meet Wall Street analysts' quarterly earnings forecasts for just seven cents,

${ }^{115}$ Other factors include, foreign consolidations, market share, deregulation, and business peaks.

${ }^{116}$ Interestingly, the authors observe that shareholder value strategies operating across industries end up putting pressure announced its intention to cut 1,700 jobs in order to improve profit margins. In 2006, Alcoa planned to cut 6,700 jobs in spited of making record earnings in the first three quarters of that year. In this case, its CEO stated that the company needed to take the "difficult but necessary" steps to move forward.

In addition to increase job insecurity, the shareholder value paradigm has also been linked to declining working conditions. In this sense, for instance, Briscoe and Murphy (2012) find that financial analysts' downgrades can lead companies to cut retiree health benefits ${ }^{117}$. According to the authors: [Since] the early 1990s, large corporations have been increasingly cutting back on their earlier commitments to retirees' health benefits... As securities analysts increasingly came to view other post-employment benefits (OPEB) liabilities as a drag on future corporate earnings, they began raising the issue in earnings conference calls with managers. When analysts downgrade their recommendations for a company's stock, one way managers can respond - signaling their commitment to shareholder value creation - is to announce OPEB curtailments (pp. 555 and 570).

Actually, companies' reduced long-term commitment and increased job insecurity have reached senior executives as well. Montier (2014), for instance, shows that the average tenure for CEOs in the U.S. has been halved from almost 12 years in the 1970s to around six years in 2013. According to the author, "[It] is little wonder that CEOs may be incentivized to extract maximum rent in the mínimum time possible given the shrinkage of their time horizons" (p. 7). Higher levels of managerial turnover embeds a dangerous tacit message: everybody who makes into the top should get rich as quickly as possible by pleasing (and never contradicting) the market.

\section{PROMOTION OF AMORAL BEHAVIOR AND ETHICAL BLINDNESS}

Indoctrinating executives with the idea that their job is only to maximize stockholder's wealth may lead to two related negative consequences in terms of ethical behavior. The first one is to induce executives to act in an amoral way as prescribed by Becker's (1968) descriptive model of

on all firms to conform to those tactics.

117 The authors analyze U.S. Fortune 500 corporations from 1989 to 2009 . 


\section{REVIEW \\ OF GLOBAL \\ MANAGEMENT}

FACULTAD DE

NEGOCIOS

UPC

crime. As a result, they become convinced that a proper decision is the one that only considers its economic benefits and costs, which means that ethical concerns tends to be intentionally left aside.

Rose (2006) demonstrates the potential damaging effects of this perspective. He conducted an experiment with 34 active directors of Fortune 200 corporations ${ }^{118}$. Participants were randomly assigned to two different groups of 17 persons. They were then required to make a decision based on an ethical case involving environmental and social considerations. In short, the case portrayed a situation in which they were directors of an industry that releases two toxic byproducts into the environment with similar properties. One of the toxins has been recently regulated because scientific evidence indicates it is carcinogenic, while the other has remained unregulated. The case then asks directors whether they would allow their companies to keep issuing the second (unregulated) toxin in the environment, in spite of its known carcinogenic properties. The only difference between the two groups of participants was that the first was informed that they were board members of a corporation listed on the NYSE, while the second was informed that they were partners in a privately-held partnership. The results were striking. Among the group of directors of NYSE companies, 15 out of 17 (88\%) voted for their companies to keep issuing the carcinogenic toxin in the environment.

According to the Rose (2006), they recognized the ethical and social implications of their decisions, but believed that current corporate law requires them to pursue legal courses of action that maximize shareholder value ${ }^{119}$. In his word, [This] research finds that directors follow a hierarchy of legal compliance when making decisions that affect social responsibility...When acting in a socially responsible manner requires violation of federal/states laws or violation of the duty to maximize shareholder wealth, directors may choose to intentionally harm society. Directors are aware of the ethical implications of their

118 The participants had served on average in six boards of directors and had an average of 20 years of management experience.

119 Stout (2012) shows that this premise is simply wrong for U.S. publicly-held companies. According to her, shareholder primacy is not required by law in the U.S. and managers have wide discretion to consider other corporate constituencies in their decisions. 120 The results were completely different for the group informed that they were partners in a privately-held partnership. In this case, only 3 out of 17 (18\%) responded that they were vote for their company to keep issuing the carcinogenic toxin in the environment. decisions, but they make decisions that offer the greatest legal protection" (p. 328)120.

In Rose's experiment, directors are clearly aware of the ethical implications of their decisions. However, this is not always the case. Actually, recent studies in an emerging field of behavioral ethics shows that we are often subject to "ethical blind spots" that lead us to behave unethically and against our values without noticing (Bazerman and Tenbrusel, 2011; Palazzo et al., 2012; Ariely, 2013) ${ }^{121}$.

The second related critique, in terms of ethical behavior, against indoctrinating executives with the belief that theirs job consists solely of maximizing stockholders' wealth, therefore, is that shareholder value ideology significantly contributes to the process of "ethical blindness" that leads normal people making unethical decisions. This term has been coined by Palazzo et al. (2012) in a paper in which they model unethical decisions as the result of an interplay between personal traits of the decision maker and characteristics of the situation in a process that unfolds over time. They define ethical blindness as "the temporary inability of a decision maker to see the ethical dimension of a decision at stake" (p. 325). Under Palazzo et al. (2012) view, people become ethically blind because they apply a limited and rigid perspective of reality when making decisions. This "rigid framing"122 is reinforced by contextual pressures that can be divided into proximal and distal factors. The proximal context includes situational as well as organizational factors, while the distal context describes the overarching institutional context in which individuals and organizations are embedded.

In their model, shareholder value ideology acts as part of an institutional context that pressures managers to disregard the ethical implications of their acts. In their words, key (implicit) assumptions of rigid economic, legal and scientific framing are that profit maximization is inherently moral, that laws are the only moral limit to profits and that scientific expertise should prevail over the concerns

Another ethical case was applied to both groups presenting a lower level of social threat. The results were qualitatively the same. ${ }^{121}$ According to Palazzo et al. (2012), "often, however, (un)ethical decision making is less rational and deliberate but more intuitive and automatic. As a consequence, the ethical dimension of a decision is not necessarily visible to the decision maker. People may behave unethically without being aware of it - they may even be convinced that they are doing the right thing. It is only later that they realize the unethical dimension of their decision" (p. 323). 122 This term is also originally created by Palazzo et al. (2012). ${ }^{123}$ In a related paper, Gonin et al. (2012) argue that "the dark side 
of affected laypersons, respectively. People who use those frames do not necessarily make unethical decisions.

However, using these frames rigidly increases the probability that people don't see the ethical dimension of their decision. (p. 327) ${ }^{123}$

Stout $(2011,2014)$ also reveals how our capacity to behave ethically depends on the social context as well as how contextual changes can produce dramatic changes in observed behavior. She argues that four social cues seem to trigger ethical and prosocial behavior: (1) instructions from authority; (2) perceptions of common "in-group" status; (3) expectations regarding others' prosociality; and, (4) magnitude of the benefits to others from one's own unselfish action. According to Stout (2014) [The] result somewhat resembles the fictional protagonista of the tale The Strange Case of Dr. Jekyll and Mr. Hyde. Sometimes we are caring, conscientious, and considerate of others' welfare (Dr. Jekyll). Sometimes we are selfish and asocial (Mr. Hyde). Which persona dominates in any particular situation seems determined largely by social context (p. 23).

A recent paper by Cohn et al. (2014) demonstrates how the context may induce people to behave unethically. They conduct and experiment with 128 employees from a large bank ${ }^{124}$. For half, they asked questions about their professional background in order to salient their professional identity ${ }^{125}$. For the other half (the control condition), they asked questions unrelated to their profession. The subjects then tossed a coin ten times. Participants were unobserved and reported the outcome online. For each toss, they could win US\$2O depending on whether they reported heads or tails ${ }^{126}$. The expected distribution of earnings

of organizations (the 'barrels') and their members (the 'apples') cannot be addressed properly without a clear understanding of the context in which they operate (the 'larder'). As we argue below, the institutionalized view of the roles and responsibilities of individual and organizational actors has an impact on how they behave. Business decisions are not made in a vacuum but are embedded in normative forces that are stronger than the organizations themselves" (p. 31).

124 On average, the bank employees had 11.5 years of experience in the banking industry. Roughly half of them worked in a core business unit, that is, as private bankers, asset managers, traders or investment managers.

125 This is a process called as "priming" in the psychology literature. It refers to activating particular representations or associations in memory just before carrying out a task. Examples of the questions used by Cohn et al. (2014) to prime the participants are "At which bank are you presently employed?" or "What is your function at this bank?". if everyone behaved honestly matched perfectly with the distribution observed in the control group ${ }^{127}$. Bank employees, therefore, have proved to be honest under normal conditions. However, a significant difference was observed in the group of bank employees exposed to their professional identity before the test. On average, they reported 58.2\% successful coin flips, significantly above chance and the control group. Bank employees, therefore, behave unethically once they were remembered of their jobs prior to the task.

Strikingly, around 8\% of the bankers in the professional identity condition claimed the maximum earnings of US\$200 (all heads or tails in a row), against an expected zero percent if everyone behaved honestly. Several bank employees, therefore, started to behave as pure homo economicus once their professional identities became salient, leaving aside any ethical concerns ${ }^{128}$. Cohn et al. (2014) summarize by saying that: Our results suggest that the prevailing business culture in the banking industry favors dishonest behavior and thus has contributed to the loss of the industry's reputation. In contrast to their public image however, we find that bank employees behave honestly on average in the control condition (p. 3) ${ }^{129}$.

\section{DETERIORATION OF LONG-TERM FIRM PERFORMANCE}

A somewhat ironic criticism to the mantra of shareholder value is that, in spite of its alleged focus on maximizing

\footnotetext{
${ }^{126}$ In order to mimic the competitive nature of the banking profession, subjects were informed that their earnings would only be paid out if they were higher or equal to those of a randomly drawn subject from a pilot study. 127 On average, participants from the control group reported successful coin flips in $51.6 \%$ of the cases, which is not significantly different from the expected 50\% if everyone behaved honestly. 128 Given that there was no chance of being caught cheating, it would have been "economically rational" to argue that all tosses resulted in the outcome that would entail the maximum economic payoff. The authors also asked subjects about the extent to which they endorse the statement that social status is primarily determined by financial success. They find that subjects in the professional identity condition endorsed the statement significantly more strongly than those in the control condition. This stronger endorsement, in turn, has shown to be positively correlated with the reported number of successful outcomes. ${ }^{129}$ A recent global survey from The Economist Intelligence Unit
} 


\section{REVIEW \\ OF GLOBAL \\ MANAGEMENT}

FACULTAD DE

NEGOCIOS

UPC

stockholder's wealth, its adoption ends up leading to wrong decisions that harm its own shareholders in the long run.

Stout (2012) provides an interesting metaphor to this adverse outcome called "fishing with dynamite". Her idea is to demonstrate how companies can use strategies to unlock shareholder value to short-term investors while reducing aggregate stockholder wealth over the long term. The metaphor is based on a hypothetical statistical analysis aiming to relate the techniques of individual fishermen in a lake with the amount of fish they catch: [What] if some fishermen start using dynamite in the lake and gather up all the dead fish that float to the surface after a blast? The statistical analysis would say that individuals who fish with dynamite catch far more fish. Then other fishermen would follow suit and start using this technique. But, over the long-run, communities that fish with dynamite typically see long-run declines in the average haul... Fishing with dynamite is a good strategy for an individual fisherman, for a while. But in the long run, it is very bad for fish and fishermen collectively (p. 50). Her point, therefore, is that companies that "fish with dynamite" may observe an initial run-up in its stock prices associated with poorer performance in the long-term.

Curiously, the anecdotal evidence provided by GE, the historic poster boy of the shareholder value movement, seems to support her view. The company has suffered a complete restructuring after its iconic CEO Jack Welch took office in 1981. Willing to please the market as part of his priority to raise stock prices, he implemented the whole set of prescriptions embedded in the shareholder value paradigm: severe downsizing, closure or selling of less profitable units, carrying out of several spin-offs and acquisitions, providing of earnings guwidance, systematic meeting of quarterly earnings per shares expected by securities' analysts, adoption of stock options plans as well as of Darwinian performance assessments, etc.

also observes cultural problems in the financial services industry. Among the 382 financial executives surveyed, 53\% think that their career progression would be difficult without being flexible on ethical standards, while a similar proportion thinks their firms would be less competitive as a consequence of being too rigid in this area. Source: The Economist Intelligence Unit. A Crisis of Culture: Valuing Ethics and Knowledge in the Financial Services. 2014

130 Source: The Economist. Electric shock: GE breaks up.Apr 10th 2015. Available at http://www.economist.com/node/21642356 131 Source: The Economist. General Electric: Back to Business. Apr 18th 2015. Available at http://www.economist.com/node/21648617 132 According to The Economist: "Its easy earnings were a form
It also went through an intense process of financialization, becoming more and more involved with the financial sector through GE Capital, its finance arm. At the end of Welch's two-decade tenure, results could not seem better. The company's market capitalization rose from US $\$ 14$ billion to US $\$ 470$ billion in December 2000, making GE the most valuable company in the world. At that point, GE Capital obtained a return on equity of $23 \%$ and represented $41 \%$ of its profits ${ }^{130}$. Welch was so celebrated by the market at that point that Fortune named him the "manager of the century" in 1999.

The long-term outcome of Welch's business model ("near suicidal" and "a disaster waiting to happen"131 according to The Economist), have only started to become clear afterwards. The strategic shift of the company to the financial industry under his command had more to do with opportunism than with corporate identity: GE simply made this move because it seemed to be an easy way to make money ${ }^{132}$. The company borrowed cheaply due to its triple-A credit rating, becoming America's biggest private issuer of short-term debt ${ }^{133}$. GE capital assets peaked half a trillion dollars on the eve of the 2008 global financial crisis, a similar figure as of Lehman Brothers. With the eruption of the crisis, GE capital could not roll over around US\$72 billion of commercial paper. The firm collapsed to a point it had to receive a government bailout of US $\$ 60$ billion in guarantees for its debt. In its aftermath, regulations for the financial sector increased, requiring more transparency and equity capital from the players.

In what was considered by The Economist "a landmark in American capitalism" 134, Welch's successor, Jeffrey Immelt, finally announced in April 2015 that GE was going to quit its financial $\mathrm{arm}^{135}$. According to the publication, "Mr. Immelt has finally stamped his mark on GE, in a way that is damaging for the reputation of Mr. Welch"136.

of corporate opium that the firm was addicted to". 133 Source: The Economist. General Electric: Back to Business. Apr 18th 2015. According to the publication, since GE was not deemed a bank by regulators, it was allowed even thinner capital buffers than many lenders had.

134 Source: The Economist. General Electric: Back to Business. Apr 18th 2015.

$135 \mathrm{GE}$ plan is to shrink its finance arm to below $10 \%$ of profits by 2018 , reducing it to the traditional role of providing credit for customers of GE products.

136 Source: The Economist. Electric shock: GE breaks up. Apr 10th 2015. 
The outcome for GE long-term stockholders since its move towards the shareholder value tenets may be considered disappointing. On May 7th 2015, its market capitalization was US\$272 billion, $40 \%$ below its market value of US $\$ 470$ billion fifteen years before in $2000^{137}$. It no longer boasts its longstanding AAA credit rating ${ }^{138}$. From August $1981^{139}$ until May 2015, the average annual increase in GE market capitalization for its stockholders was a modest 9.1\%, similar to the $8.7 \%$ return of the S\&P 500 index in the same period. In fact, it is important to note that GE beta is 1.34 , which means that it is significantly more risky than the broad market portfolio. As a result, a "fair return" to its stockholder should have been far higher than the return of the S\&P500 index in the period ${ }^{140}$. A simplified exercise shows that this was clearly not the case. Using the average market risk premium of 5\% observed between 1981 and 2015, for instance, GE's expected return should have been 10.4\% according to the standard CAPM model. Thus, the GE stock return since 1981 was lower than it would have been fair for its stockholders.

The adverse consequences for GE's shareholders resulting from its structural shifts under Welch's tenure are perhaps even of more concern than unsatisfactory risk-adjusted returns. Firstly, GE's corporate identity has been severely harmed. According to The Economist, $60 \%$ of its sales in 2001 came from business that GE no longer owns. Its industrial division has bought or sold companies worth US $\$ 100$ billion in the 2000 decade, more than the capital currently invested in the business that remains. The magazine recognizes that "[This] means GE's industrial businesses have not been a rock, but a constant shifting portfolio of assets - rather like a financial firm, in fact" 141 Secondly, the changes seem to have reduced the innovation

\footnotetext{
${ }^{137}$ In the same period, GE fell from 1st to 9th place among the most valuable companies, while its revenues increased slightly (not accounting for inflation) from US $\$ 130$ billion in 2000 to US\$144 billion in 2014.

138 On May 31st 2015, General Electric company credit rating was A1 from Moodys and AA+ form Standard \& Poor's. GE Capital rating was Baa1 and $A^{+}$, respectively. http://www.ge.com/ investor-relations/fixed-income-investors

139 In August 1981, Jack Welch gave his first speech as the GE CEO at the hotel Pierre in New York. The speech, entitled "Growing fast in a slow-growth economy", is considered the initial landmark of the shareholder value movement.

${ }^{140}$ A simplified exercise shows that this was clearly not the case. By using the average market risk premium of $5 \%$ between 1981 and 2015, for instance, GE's expected return should have been 10.4\%. In other words, GE stock returns since 1981 has been unsatisfactory even to be considered a fair return based on the standard CAPM model.
}

capacity and efficiency of its traditional business. Both net profits and cash flows from GE's industrial units fell around 50\% from 2008 to 2014. This, in turn, has led to a growing doubt whether its industrial businesses will be able to resume growth in the coming years. The Economist summarizes this skepticism by saying that "[By] announcing the closure of GE's financial arm, Jeffrey Immelt has only won half of the battle to save the company" 142

There are no (to my knowledge) academic studies analyzing the long-term impact of companies that embraced more closely the tenets of shareholder value vis-à-vis other firms using large datasets and appropriate econometric procedures. In lack of these studies, critics tend to use aggregate data from broad stock indices to show that the rise of the shareholder value has not been followed by an overall improvement of stock returns for shareholders in general. In this sense, Stout (2012) shows that the average return of the S\&P 500 was 7.5\% per year between 1933 and 1976 (the year of the Jensen and Meckling classic paper), against only 6.5\% per year from 1976 to 2011, a period in which this dogma gained prominence in the business world.

\section{WORST LONG-TERM OUTCOMES FOR CAPITAL MARKETS, THE ENVIRONMENT, AND UNIVERSAL INVESTORS}

The last alleged toxic effect resulting from the shareholder value paradigm deals with its aggregate impact on capital markets, the economy and sustainability. In this case, critics link the rise of the ideology in the 1980s with the deterioration of several indicators related to these issues.

\footnotetext{
${ }^{141}$ GE's decisions fit perfectly in Fligstein (1990) view that non-financial corporations came to be increasingly seen as bundles of assets, rather than firm's with product-centered identities.

142 Source: The Economist. Banking on de-banking. Apr 18th 2015. Available at http://www.economist.com/node/21648681/. Interestingly, The Economist made several compliments to Welch when he retired from the company in 2000. Among others, the publication stated that "Such perfectionism stems from Jack Welch, GE's boss since 1981, who has some claim to being the world's most successful manager of the past quartercentury"; "it is American firms' Welchian willingness to take hard decisions that has given American business its current pre-eminence"; and, that "It is this relentlessness that makes GE both so successful and so hard to copy". Source: The Economist. The house that Jack built. Sep 16th 1999. Available at http://
} 


\section{REVIEW}

OF GLOBAL

MANAGEMENT

FACULTAD DE

NEGOCIOS

UPC

To begin, market characteristics associated with the shareholder value doctrine, such as the pressure for short-term returns, or the increased threat of being acquired or to become target of shareholder class-action lawsuits, may have driven away companies from stock markets. According to the CFA Institute, global equity listings declined 17\% between 1998 and $2012^{143}$. The figures are even more dramatic for the U.S., where stock exchanges lost nearly 50\% of their listings from their peak of 9,253 in 1997.

IPO market activity also has suffered. According to Ritter (2013), from 1980-2000, an annual average of 310 companies went public in the U.S. This number has fallen to only 99 companies in the 2001-2011 period ${ }^{144}$. The author observes that the frequency of being acquired within three years of going public has increased over time, with the uptrend starting in the early 1990s. He also notes that, once a company is public, it is increasingly threatened by shareholder class-action lawsuits, resulting in higher insurance premiums than if the company had remained private.

The reduction in IPO market activity has also had macroeconomic implications in terms of employment. Ritter (2013) finds that the 2,766 domestic companies that went public in the U.S. from 1996 to 2010 added on average 822 employees per firm since its IPOs. After calculating the number of jobs that would have been added to the economy if the number of IPOs had not dropped in the country, he reaches a staggering figure of 1.87 million jobs not "created" due to the IPO shortfall.

According to the Aspen Institute (2010), short-termism based on an excessive emphasis on current stock prices may also lead to mispricing of assets due to a lack of reliable information about long-term prospects. This, in turn, would be an additional factor leading to fewer listings on stock markets. Taken to a national level, the systemic underinvestment in R\&D due to short-termism might affect competitiveness and economic growth.

Masouros (2012) corroborates this view. He concludes that

www.economist.com/node/239557

${ }^{143}$ The number of listed companies worldwide has fallen from 56,119 to 46,674 during this period.

${ }^{144}$ He notes that the decline has been even more severe for the IPO of small companies. In this case, the figure has dropped 83\%, from 166 IPOs per year during 1980-2000 to only 29 per year during 2001-2011. the shift in the institutional logics of corporate governance towards shareholder value coupled with investors' increasing short-termism have cumulatively contributed to lower levels of capital investment by firms, economic stagnation, and lower GDP growth rates in five major Western economies: the U.S., the U.K., the Netherlands, France, and Germany.

Tomaskovic-Devey et al. (2015) provides additional evidence at the industry level. They investigate the consequences of the orientation to shareholder value by non-financial firms, finding that this shift has decreased total valueadded in the non-finance economy. They also find that the reduction in overall economic growth due to the financialization of the non-finance sector has been largely borne by labor and the state, while increasing value has been channeled to corporate debt and equity holders.

Another related critic is that the emergence of the shareholder value paradigm has contributed to a reduction in the lifetime of public companies. According to Montier (2014), for instance, the average lifespan of a company in the S\&P 500 has been almost halved from 27 years in 1980 to only 15 years in 2013.

In addition to these concerns, some scholars argue that the shareholder value idea is simply outdated for the 21st century because it does not consider the new imperatives of environmental sustainability as well as the rise of the universal investors.

In the first case, Sjåfjell and Mähönen (2014) and Sjåfjell et al. (2014) summarize the findings of a three-year project involving more than 40 legal scholars who mapped the law in 26 jurisdictions across the globe. They find that, although no company law system requires directors to pursue shareholder profit maximization at all costs, the social norm nowadays pressures board members to do just this. In their view, the focus on shareholder value constitutes the main barrier for companies to become sustainable from an environmental perspective ${ }^{145}$. As a result, they conclude that corporate law around the world should be

\footnotetext{
145 The urgent call for a sustainable society is highlighted by striking figures from environmental reports such as World Wildlife Fund (WWF) "Living Planet Report 2014". It shows that more than half of the animals in the world have disappeared since 1970. The report also warn that human activity is depleting Earth's resources by cutting down forests too quickly overfishing and putting out more carbon dioxide than the planet can absorb. Available at https://www.worldwildlife.org/ press-releases/half-of-global-wildlife-lost-says-new-wwf-report
} 
reformed in order to clearly require boards to prioritize environmental sustainability over maximum returns for stockholders.

In the second case, the shareholder value dogma does not consider that an increasing proportion of investors nowadays are "universal" through their diversified portfolios. These investors are, at the same time, consumers, employees, and citizens from the communities impacted by the companies. The relation with their companies, therefore, goes far beyond their equity holdings: they are also stakeholders interested in the aggregate outcomes from listed companies as well as in the long-term wellbeing of society.

Universal investors bear the costs of most of the externalities released by companies. According to a United Nations report from $2011^{146}$, for instance, the cost of environmental damage caused by the world's 3,000 largest listed companies totaled US\$2.15 trillion in 2008. Thus, the cost that shareholders bear due to the externalities released by their companies is often higher than the financial gain coming from them in the form of dividends and stock returns. In other words, ordinary people may be providing the capital that is being used against them by companies that are myopically focused on stock prices.

\section{CONCLUDING REMARKS}

The business world has changed substantially since the early 1980s due to the popularization of shareholder value maximization as the main mission to be pursued by corporate managers. Although this shift has been more pronounced in the U.S. and in the U.K., the intellectual leadership of these countries in the management sphere has strongly disseminated this mantra around the world.

The empirical and theoretical literature surveyed in this paper shows that governing companies in order to maximize current stock prices lead to severe negative outcomes for all its constituencies, including society and shareholders themselves. It also adds to the literature by providing anecdotal evidence through short business cases of these side effects.

The review of the literature provides compelling evidence

146 United Nations Environment Programme Finance Initiative (UNEP FI). Universal Ownership: Why environmental externalities matter to institutional investors. Available at http://www. that the quest to maximize stock prices fosters a short-term orientation in the governance of companies. It shows that the problem of short-termism derives from market pressures imposed on managers--e.g., such as the permanent threat of being acquired and the imperative to systematically meet expected earnings per share--as well as from distorted equity-based compensation systems. These forces lead to underinvestment as well as to the process of financialization of companies. The mantra of shareholder value maximization also incentivizes managers to make systematic announcements in order to signal their conformity with this dogma, such as downsizing, M\&As operations and stock buybacks. The impacts of this paradigm are also felt in the workplace. Companies tend to develop an organizational culture based on internal competition, insecurity, fear, aggressiveness and Darwinian performance assessments. Corporate identity tends to fade, leading to lack of meaning and sense of purpose among employees. Ethical problems are likely to take place more often because executives are taught that their decisions should be strictly based on "economic logic", which in turn leads to amoral behavior and ethical blindness.

From a broader perspective, society also is affected when managers seek to maximize returns to shareholders at all costs. Rents tend to be extracted by pressuring stakeholders, such as employees, suppliers and communities. Companies are prone to hide potential liabilities as well as to not bear the costs of their externalities unless they are obliged to do so. Everyone, including future generations, tends to suffer the consequences of this narrow approach to business eventually, resulting in a big tragedy of commons.

Curiously, long-term shareholders are one of the most impacted constituencies. As stockholders, they bear the consequence of the likely deterioration of their firms' performance in the long run. As universal investors, they bear the costs of its social and environmental externalities as well as end up working in harsh organizational environments generated by this managerial paradigm. As citizens, they end up living in a society that largely reflects the quality of the decisions of these powerful institutions.

The limitations and adverse consequences from the shareholder value approach have started to be recognized

unepfi.org/fileadmin/documents/universal_ownership_full.pdf 


\section{REVIEW}

OF GLOBAL

MANAGEMENT

FACULTAD DE

NEGOCIOS

UPC

by some corporate managers. Paul Polman, CEO of Unilever, illustrates the growing awareness among executives to adopt a broader perspective for their role by declaring that "[I] do not work for the shareholder, to be honest; I work for the consumer, the customer [...] I'm not driven and I don't drive this business model by driving shareholder value" ${ }^{148}$.

Even Jack Welch, the executive that for many symbolizes this doctrine, has recently argued that managers should not set share price increases as their overarching goal and that "[Shareholder] value is a result, not a strategy... Your main constituencies are your employees, your customers and your products... On the face of it, shareholder value is the dumbest idea in the world"149.

The view that managers should not run companies focusing on current stock prices, therefore, seems today to be increasingly accepted. However, the debate on the appropriate mission to be pursued by corporate managers is still far from settled. Instead of "immediate" shareholder value, most of its former supporters are adjusting their discourses to "long term" shareholder value maximization.

The more controversial debate, therefore, is whether shareholder primacy should still hold as the backbone for the corporate governance movement. If not, then a new and consensual platform for the role of managers should replace it, prioritizing above all the public interest; the company's best interests ${ }^{150}$; or the balanced interests of all stakeholders. For Stout (2012), for instance, it is clear that "shareholder primacy thinking in its conventional form is on the brink of intellectual collapse, and will be replaced by more sophisticated and nuanced theories of corporate structure and purpose"151.

Thus, the background issue related to this paper is whether managers' mission is just to maximize the long-term economic results for stockholders or to have a broader accountability encompassing other stakeholders

\footnotetext{
148 Source: Financial Times. "Unilever warning on 'shareholder value'". 04/04/2010. Available at http://on.ft.com/1KtVijq ${ }^{149}$ Source: Financial Times. "Welch condemns share price focus". 12/03/2009. Available at http://on.ft.com/vXOXup

${ }^{150}$ The company's interests is a concept that transcends the interests of shareholders by including those of other stakeholders, such as employees, customers, creditors, suppliers, communities, and society. The premise for this view is that, although the long-term interests of the company as an entity and of its shareholders are congruent on most occasions, they may sometime diverge.

${ }^{151}$ In her work, Stout (2012) reviews five alternative new
}

and society; whether managers should act as amoral agents within the law or if they should be expected to make ethical decisions; whether public companies are only money machines or above all social institutions. The ultimate debate is to revisit the purpose of the public company beyond shareholder value maximization in order to reconnect it to society ${ }^{152}$.

\section{REFERENCES}

Achtziger, A., Alós-ferrer, C., Hügelschäfer, S., \& Steinhauser, M. (2015). Higher incentives can impair performance: Neural evidence on reinforcement and rationality. Social Cognitive and Affective Neuroscience Advance, 1, 1-7.doi:10.1093/scan/ nsv036

Aebi, V., Sabato, G., \& Schmid, M. (2012). Risk management, corporate governance, and bank performance in the financial crisis. Journal of Banking \& Finance, 36, 3213-3226. doi:10.1016/j.jbankfin.2011.10.020

Aglietta, M. (2000). Shareholder value and Corporate Governance: Some tricky questions. Economy and Society, 29(1), 146-159. doi: 10.1080/030851400360596

Alvarez, I. (2015). Financialization, non-financial corporations and income inequality: The case of France. Socio-Economic Review, 1,1 - 27. doi:10.1093/ser/ mwv007

Anabtawi, I., \& Stout, L. (2008). Fiduciary duties for activist shareholders. Stanford Law Review, 60(5), 1255-1308. Retrieved from https://www.jstor.org/ stable/40040386

corporate theories which suggest that conventional shareholder primacy is counterproductive: 1) Market inefficiency and divide between short-term speculators and long-term investors; 2) Capital "lock in" and differences in shareholders' demands for liquidity; 3) Team production theory and the problem of ex post shareholder opportunism; 4) Undiversified shareholders versus universal investors; and, 5) Director control and the interests of prosocial shareholders.

${ }^{152}$ An important series of debates on this subject has been carried out by The Purpose of the Corporation Project. More information available at http://www.purposeofcorporation.org/cs 
Ariely, D., Gneezy, U., Loewenstein, G., \& Mazar, N. (2009). Large stakes and big mistakes. Review of Economic Studies, 76(2), 451-469. doi: 10.1111/j.1467-937X.2009.00534.x

Ariely, D. (2013). The (Honest) Truth About Dishonesty: How We Lie to Everyone--Especially Ourselves (Reprint edition). New York, NY:Harper Perennial.

Armour, J., \& Gordon, J. (2014). Systemic harms and shareholder value. The Journal of Legal Analysis, 6(1), 35-85. doi: 10.1093/jla/lau004

Asker, J., Farre-Mensa, J., \& Ljungqvist, A. (2015). Corporate investment and stock market listing: A puzzle? Review of Financial Studies, 28(2), 342-390. doi: 10.1093/rfs/hhu077

Aspen Institute. (2010). Short-termism and U.S. capital markets: A compelling case for change. Retrieved from https://assets.aspeninstitute.org/ content/uploads/files/content/images/ Compelling\%20Case\%20for\%20Change_ August2010.pdf

Bazerman, M., \& Tenbrusel, A. (2011). Blind spots: Why we fail to do what's right and what to do about it. Princeton, NJ: Princeton University Press.

Bebchuk, L. \& Grinstein, Y. (2005). The growth of executive pay. Oxford Review of Economic Policy, 21(2), 283-303. doi:10.1093/oxrep/gri017

Becht, M., Franks, J., Mayer, C., \& Rossi, S. (2009). Returns to shareholder activism: Evidence from a clinical study of the Hermes UK focus fund. The Review of Financial Studies, 22(8), 3093-3129. doi:10.1093/ rfs/hhn054

Becker, G. (1968). Crime and punishment: An economic approach. The Journal of Political Economy, 76, 169-217. doi:10.1086/259394

Benner, M., \& Ranganathan, R. (2012). Offsetting illegitimacy? How pressures from securities analysts influence incumbents in the face of new technologies. Academy of Management Journal, 55(1), 213-233. doi:10.5465/amj.2009.0530
Blackburn, R. (2006). Finance and the fourth dimension. New Left Review, 39, 39-70.

Beltratti, A., \& Stulz, R. (2012). The credit crisis around the globe: Why did some banks perform better? Journal of Financial Economics, 105, 1-17. doi:10.1016/j.jineco.2011.12.005

Blair, M., \& Stout, L. (1999). A team production theory of corporate law. The Journal of Corporation Law, 24(4), 751-806. Retrieved from https://search. proquest.com/docview/ 220765184? accountid $=43860$

Bratton, W., \& Wachter, M. (2010). The case against shareholder empowerment. University of Pennsylvania Law Review, 158(3), 653-728. Retrieved from https://www.jstor.org/ stable/20698344

Brav, A., Jiang, W., \& Kim, H. (2008). Hedge Fund Activism: A Review. Foundations and Trends ${ }^{\oplus}$ in Finance, 4(3), 185-246. doi:10.1561/0500000026

Briscoe, F., \& Murphy, C. (2012). Sleight of hand? Practice opacity, third-party responses, and the interorganizational diffusion of controversial practices. Administrative Science Quarterly, 57(4), 553-584. doi:10.1177/0001839212465077

Budros, A. (1997). The new capitalism and organizational rationality: The adoption of downsizing programs, 1979-1994. Social Forces, 76(1), 229-250. doi:10.1093/sf/76.1.229

Bushee, B. (1998). The influence of institutional investors on myopic R\&D investment behavior. The Accounting Review, 73(3), 305-333. Retrieved from https://www.jstor.org/stable/248542

Chib, V., Shimojo, S., \& O'doherty, J. (2014). The effects of incentive framing on performance decrements for large monetary outcomes: Behavioral and neural mechanisms. The Journal of Neuroscience, 34(45), 14833-14844.doi:10.1523/JNEUROS CI.1491-14.2014 


\section{REVIEW}

OF GLOBAL

MANAGEMENT

FACULTAD DE

NEGOCIOS

UPC

Cheffins, B., \& Armour, J. (2011). The past, present, and future of shareholder activism by hedge funds. The Journal of Corporation Law, 37(1), 51-103. Retrieved from https://heinonline.org/HOL/ LandingPage? handle=hein.journals/ jcorl37\&div $=5 \&$ id $=\&$ page $=$

Clarke, B. (2010). Directors' duties in a changing world: Lessons from the Cadbury Plc takeover. European Company Law, 7(5), 204-209. Retrieved from: http://kluwerlawonline.com/abstract.php? area= Journals\&id=EUCL2010039\#

Clarke, B. (2014). The EU's shareholder empowerment model in the context of the sustainable companies agenda. European Company Law, 11(2), 103-106. Retrieved from: http://kluwerlawonline.com/abstract.php?area= Journals\&id=EUCL2014020

Cohn, A., Fehr, E., \& Maréchal, M.a. (2014). Business culture and dishonesty in the banking industry. Nature, 516, 86-89. doi:10.1038/nature13977

Deyoung, R., Peng, E., \& Yan, M. (2013). Executive compensation and business policy choices at U.S. commercial banks. Journal of Financial and Quantitative Analysis, 48(1), 165-196. doi:10.1017/ S0022109012000646

Dorff, M. (2014). Indispensable and Other Myths: Why the CEO Pay Experiment Failed and How to Fix it. Oakland, CA: University of California Press.

Duménil, G., \& Lévy, D. (2011). The Crisis of Neoliberalism. Cambridge, MA: Harvard University Press.

Erkens, D., Hung, M., \& Matos, P. (2012). Corporate governance in the 2007-2008 financial crisis: Evidence from financial institutions worldwide. Journal of Corporate Finance, 18(2), 389-411. doi:10.1016/j.jcorpfin.2012.01.005

Fahlenbrach, R., \& Stulz, R. (2011). Bank CEO incentives and the credit crisis. Journal of Financial Economics, 99(1), 11-26. doi:10.1016/j.jfineco.2010.08.010

Financial Crisis Inquiry Commision. (2011) The Financial Crisis Inquiry Report. Retrieved from https:// www.govinfo.gov/content/pkg/GPO-FCIC/pdf/ GPO-FCIC.pdf
Fligstein, N. (2001). The Architecture of Markets: An Economic Sociology of Twenty-First-Century Capitalist Societies. Princeton, NJ: Princeton University Press.

Fligstein, N., \& Shin, T. (2004). The Shareholder Value Society: Changes in Working Conditions and Inequality in the U.S., 1975-2000. In K. Neckerman (Ed.), Social Inequality (pp. 401-432). New York, NY: Russell Sage Foundation.

Fligstein, N., \& Shin, T. (2007). Shareholder value and the transformation of the U.S. economy, 1984-2000. Sociological Forum, 22(4), 399-424. doi:10.1111/j.1573-7861.2007.00044.x.

Gneezy, U., Meier, S., \& Rey-Biel, P. (2011). When and why incentives (don't) work to modify behavior. Journal of Economic Perspectives, 25(4), 191-210. doi:10.1257/jep.25.4.191

Gonin, M., Palazzo, G., \& Hoffrage, U. (2012). Neither bad apple nor bad barrel: How the societal context impacts unethical behavior in organizations. Business Ethics: A European Review, 21(1), 31-46. doi:10.1111/j.1467-8608.2011.01643.x

Graham, J., Campbell R. H., \& Rajgopal, S. (2006). Value destruction and financial reporting decisions. Financial Analysts Journal, 62(6), 27-39. doi:10.2469/faj.v62.n6.4351

Gupta, K., Krishnamurti, C., \& Tourani-Rad, A. (2013). Is corporate governance relevant during the financial crisis? Journal of International Financial Markets, Institutions and Money, 23, 85-110. doi:10.1016/j.intfin.2012.10.002

Hanley, C. (2011). Investigating the organizational sources of high-wage earnings growth and rising inequality. Social Science Research, 40(3), 902-916.doi:10.1016/j.ssresearch.2010.11.005

Hansmann, H., \& Kraakman, R. (2001). The end of history for corporate law. The Georgetown Law Journal, 89, 439-468. Retrieved from https://heinonline.org/ HOL/LandingPage? handle=hein.journals/ glj89\&div=20\&id $=\&$ page $=$ 
Jensen, M., \& Murphy, K. (1990). Performance pay and top-management incentives. The Journal of Political Economy, 98(2), 225-264. doi:10.1086/261677

Jensen, M. (2001). The Theory of the Firm: Governance, Residual Claims, and Organizational Forms. Cambridge, MA: Harvard University Press.

Jensen, M., \& Meckling, W. (1976). Theory of the firm: Managerial behavior, agency costs and ownership structure. Journal of Financial Economics, 3(4): 305-360. doi:10.1016/0304405X(76)90026-X

Jie, H., \& Xuan, T. (2013). The dark side of analyst coverage: The case of innovation. Journal of Financial Economics, 109(3), 856-878. doi:10.1016/j.jfineco .2013.04.001

Johnston, A. (2014). Reforming english company law to promote sustainable companies. European Company Law, 11(2), 63-66. Retrieved from http:// kluwerlawonline.com/abstract.php?area= Journals\&id=EUCL2014011

Jung, J. (2015). Shareholder value and workforce downsizing, 1981-2006. Social Forces, 93(4), 1335-1368. doi:10.1093/sf/sou108

Kahan, M. \& Rock, E. (2007). Hedge funds in corporate governance and corporate control. University of Pennsylvania Law Review, 155(5), 1021-1093. doi:10.2307/40041292

Kenney, M., Patton, D., \& Ritter, J. (2012). Post-IPO Employment and Revenue Growth for U.S. IPOs, June 1996-2010 (Kauffman Foundation Report). doi:10.2139/ssrn.2063829

Kliman, A., \& Williams, S. (2015). Why 'financialisation' hasn't depressed US productive investment. Cambridge Journal of Economics, 39(1), 67-92. doi:10.1093/cje/beu033

Krippner, G. (2005). The financialization of the american economy. Socio-Economic Review, 3(2), 173-208. doi:10.1093/SER/mwiO08
Krippner, G. (2011). Capitalizing on Crisis: The Political Origins of the Rise of Finance. Cambridge, MA: Harvard University Press.

Lazonick, W., \& O'sullivan, M. (2000). Maximizing shareholder value: a new ideology for corporate governance. Economy and Society, 29(1), 13-35. doi:10.1080/030851400360541

Lazonick, W. (2008). The quest for shareholder value: Stock repurchases in the united states. Louvain Economic Review, 74(4): 479-540. doi:10.3917/rel.744.0479

Lazonick, W. (2009a). The explosion of executive pay and the erosion of american prosperity. Entreprises et Histoire, 57(4), 141-164. doi:10.3917/eh.057.0141

Lazonick, W. (2009b). The new economy business model and the crisis of U.S. capitalism. Capitalism and Society, 4(2), 1-70. doi:10.2202/1932-0213.1054

Lazonick, W. (2010). Innovative Business models and varieties of capitalism: Financialization of the US corporation. Business History Review, 84(4), 675-702. doi:10.1017/S0007680500001987

Lazonick, W. (2011). From innovation to financialization: How shareholder value ideology is destroying the US economy. In M. Wolfson, \& G. Epstein (Eds.), The Handbook of the Political Economy of Financial Crises (pp. 491-511). Oxford, UK: Oxford University Press

Lie, E. (2005). On the timing of CEO stock option awards. Management Science, 51(5), 802-812. doi:10.1287/ mnsc.1050.0365

Lin, K. H. \& Tomaskovic-Devey, D. (2013). Financialization and U.S. income inequality, 1970-2008. American Journal of Sociology, 118(5), 1284-1329. doi:10.1086/669499

Martin, R. (2010). The age of customer capitalism. Harvard Business Review, 88(1), 58-70. Retrieved from https://hbr.org/2010/01/the-age-of-customercapitalism 


\section{REVIEW}

OF GLOBAL

\section{MANAGEMENT}

FACULTAD DE

NEGOCIOS

UPC

Martin, R. (2011). Fixing the Game. Cambridge, MA: Harvard Business Review Press.

Masouros, P. (2012). Corporate Law and Economic Stagnation: How Shareholder Value and Short-Termism Contribute to the Decline of the Western Economies (Doctoral Thesis, Leiden University, The Netherlands). Retrieved from https://openaccess.leidenuniv.nl/handle/ 1887/19835

Mayer, C. (2013). Firm Commitment: Why the corporation is failing us and how to restore trust in it. Oxford, UK: Oxford University Press.

Montier, J. (2014). The World's Dumbest Idea (GMO White Paper). Retrieved from https://www.gmo.com/ globalassets/articles/white-paper/2014/jm_theworlds-dumbest-idea_12-14.pdf

Ott, J. (2011). When Wall Street Met Main Street: The Quest for an Investors' Democracy. Cambridge, MA: Harvard University Press.

Palazzo, G., Krings, F., \& Hoffrage, U. (2012). Ethical Blindness. Journal of Business Ethics, 109(3), 323-338. doi:10.1007/s10551-011-1130-4

Pearlstein, S. (2014). Social Capital, Corporate Purpose and the Revival of American Capitalism (Paper from the Center for Effective Public Management at Brookings Institution). Retrieved from https:// www.brookings.edu/wp-content/uploads/ 2016/06/BrookingsPearlsteinv5_Revised-Feb -2014.pdf

Piketty, T., \& Saez, E. (2006). The evolution of top incomes: A historical and international perspective. American Economic Review, 96(2), 200-205. doi:10.1257/000282806777212116

Rappaport, A. (1986). Creating Shareholder Value: The New Standard for Business Performance. New York, NY: The Free Press.

Ritter, J. (2013). Re-energizing the IPO market. In M. Baily, R. Herring, \& Y. Seki (Eds.), Financial Restructuring to Sustain Recovery (123-146). Retrieved from https://www.jstor.org/stable/10.7864/j.ctt6wpcrp
Roe, M. (2014). Structural corporate degradation due to too-big-to-fail finance. University of Pennsylvania Law Review, 162(6), 1419-1464. Retrieved from https://www.jstor.org/stable/24247857

Rose, J. (2006). Corporate directors and social responsibility: Ethics versus shareholder value. Journal of Business Ethics, 73(3), 319-331. doi:10.1007/s10551006-9209-z

Saez, E. (2013). Striking it Richer: The Evolution of Top Incomes in the United States (Updated with 2012 preliminary estimates). Retrieved from htps: //www.nuevatribuna.es/media/nuevatribuna/ files/2015/02/05/saez-ustopincomes-2013.pdf

Sjåfjell, B., Johnston, A., Anker-Sørensen, L. \& Millon, D. (2014, September). Shareholder Primacy: The Main Barrier to Sustainable Companies (University of Oslo Faculty of Law Research Paper No. 2015-37). Retrieved from https://ssrn.com/abstract=2664544

Sjåfjell, B., \& Mähönen, J. (2014). Upgrading the Nordic corporate governance model for sustainable companies. European Company Law, 11(2), 58-62. Retrieved from http://ssrn.com/abstract=2471495

Shin, T. (2012). CEO compensation and shareholder value orientation among large US firms. The Economic and Social Review, 43(4), 535-559. Retrieved from https://www.esr.ie/article/view/36

Stockhammer, E. (2004). Financialisation and the slowdown of accumulation. Cambridge Journal of Economics, 28(5), 719-741. doi:10.1093/cje/beh032

Stout, L. (2002). Bad and Not-So-Bad Arguments for Shareholder Primacy. Southern California Law Review, 75, 1189-1209. Retrieved from https:// heinonline.org/HOL/LandingPage?handle=hein. journals/scal75\&div=37\&id $=$ \&page $=$

Stout, L. (2010). Cultivating Conscience: How Good Laws Make Good People. Princeton, NJ: Princeton University Press.

Stout, L. (2012A). The Shareholder Value Myth. Oakland, CA: Berret-Koehler Publishers. 
Stout, L. (2012b). New thinking on "shareholder primacy". Accounting, Economics, and Law, 2(2), 1-24. doi:10.1515/2152-2820.1037

Stout, L. (2013). The toxic side effects of shareholder primacy. University of Pennsylvania Law Review, 161(7), 2003-2023. Retrieved from https://www.jstor.org/ stable/23527857

Stout, L. (2014). Killing conscience: The unintended behavioral consequences of "pay-for-performance". Journal of Corporate Law, 39, 525-566. Retrieved from https://heinonline.org/HOL/LandingPage? handle=hein.journals/jcorl39\&div=24\&id=\&page=

Tomaskovic-Devey, D., Lin, K.h., \& Meyers, N. (2015). Did financialization reduce economic growth? Socio-Economic Review, 13(3), 525-548. doi:10.1093/ser/mwv009

Tsagas, G. (2014). A long-term vision for UK firms? Revisiting the target director's advisory role since the takeover of Cadbury's PLC. Journal of Corporate Law Studies, 14(1), 241-275. doi:10.5235/14735970.14.1.241

Van Der Zwan, N. (2014). Making sense of financialization. Socio-Economic Review, 12(1), 99-129. doi:10.1093/ ser/mwt020

Wolfson, M. H., \& Kotz, D. M. (2010). A reconceptualization of social structure of accumulation theory. In T. McDonough, M. Reich, \& D. M. Kotz (Eds.), Contemporary Capitalism and its Crises: Social Structure of Accumulation Theory for the 21st Century (pp. 72-90). New York, NY: Cambridge University Press.

Yermack, D. (2010). Shareholder voting and corporate governance. Annual Review of Financial Economics, 2, 103-125. doi: 10.1146/annurev-financial-073009-104034 